\title{
MARINe ARChAEOLOGY SURVEY IN SuPPORT OF GALVESTON ISLAND STATE PARK Marsh Restoration and Protection Project Galveston County, TeXas
}

Prepared for:

HDR Engineering, Inc.

555 N Carancahua, Suite 1600

Corpus Christi, TX 78401

Prepared by:

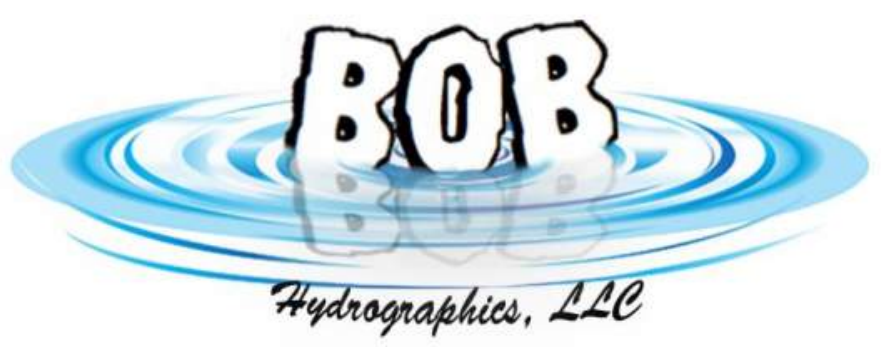

BOB Hydrographics, LLC

1315 Fall Creek Loop Cedar Park, Texas 78613

Principal Investigator:

Robert Gearhart

June 2019 
BOB Project 2019-04

\author{
MARINE ARCHAEOLOGY SURVEY \\ IN SUPPORT OF GALVESTON ISLAND STATE PARK \\ MARSH RESTORATION AND PROTECTION PROJECT \\ GALVESTON COUNTY, TEXAS \\ Texas Antiquities Permit No. 8906
}

Prepared for:

HDR Engineering, Inc. 555 N Carancahua, Suite 1600

Corpus Christi, TX 78401

Prepared by:

BOB Hydrographics, LLC

1315 Fall Creek Loop

Cedar Park, Texas 78613

Principal Investigator:

Robert Gearhart

June 2019 


\section{Table of Contents}

Page

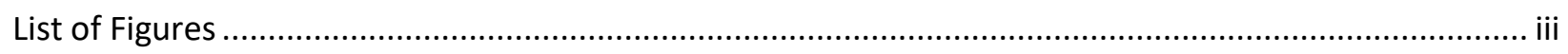

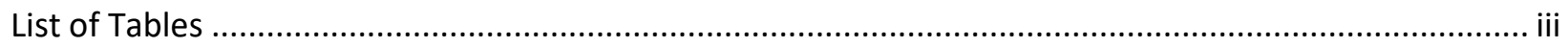

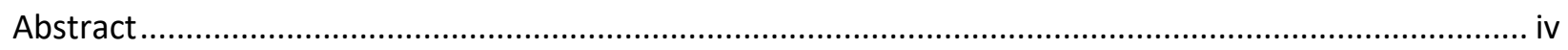

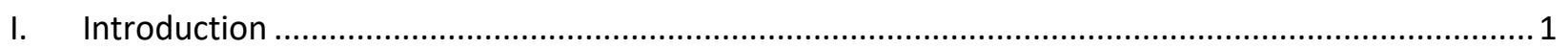

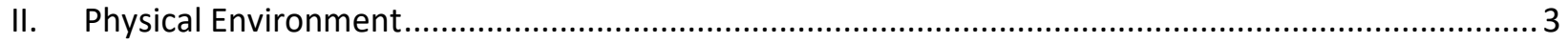

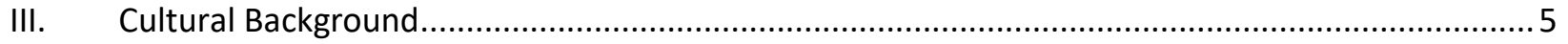

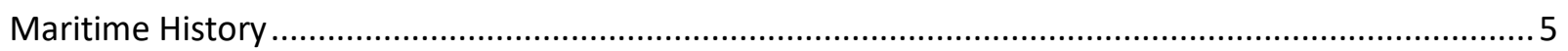

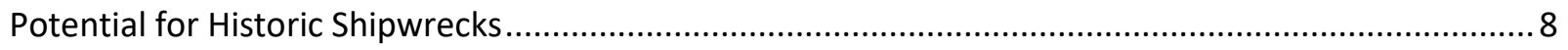

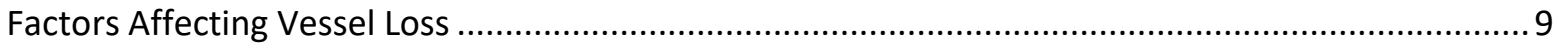

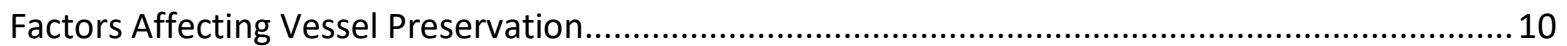

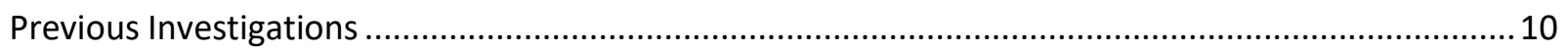

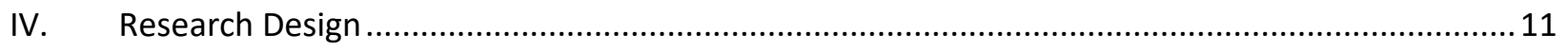

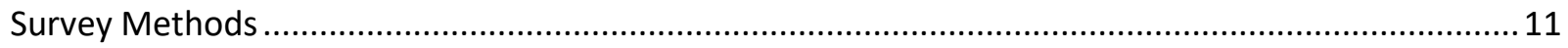

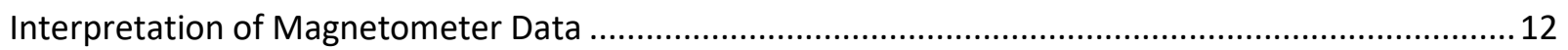

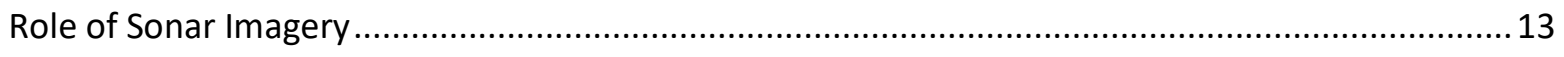

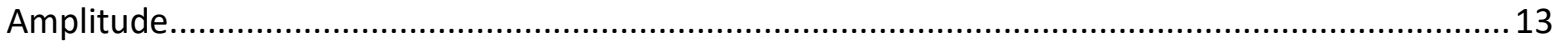

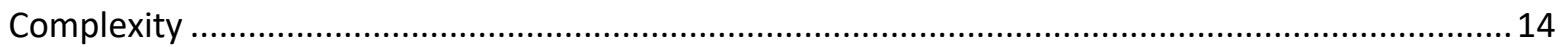

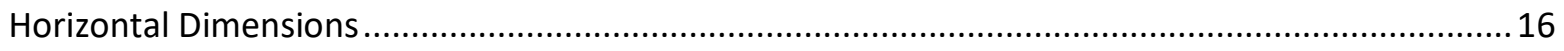

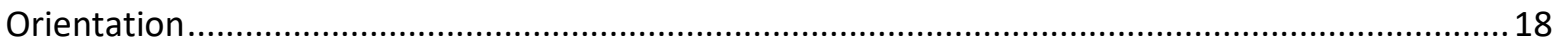

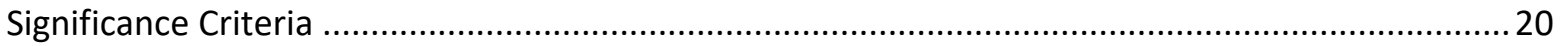

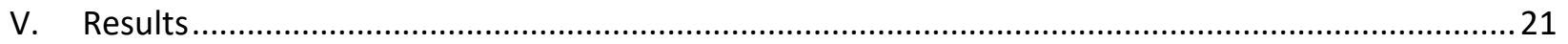

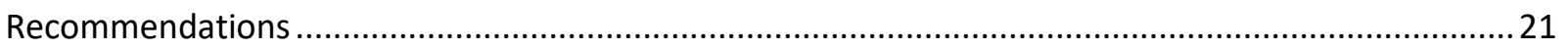

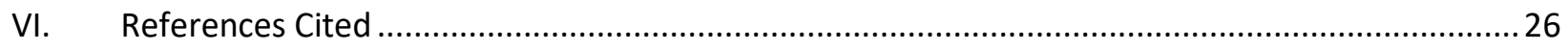

Appendix A: Texas Antiquities Permit 8906 and THC Correspondence............................................. A-1 


\section{List of Figures}

Page

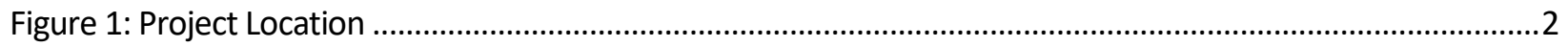

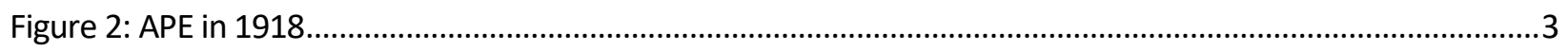

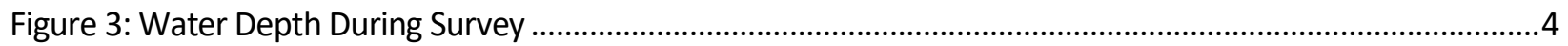

Figure 4: Example of a Verified Shipwreck Anomaly, Site 41CL92 ................................................................15

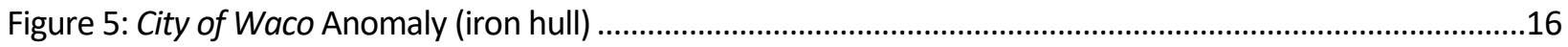

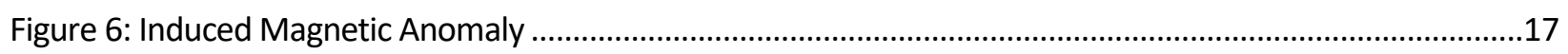

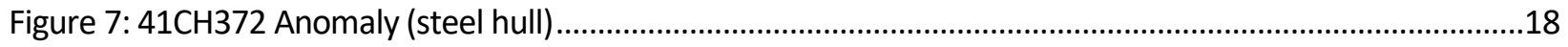

Figure 8: Mag-13 Wreck Anomaly (wooden hull)..........................................................................................19

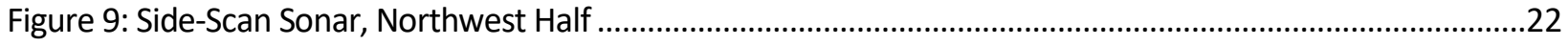

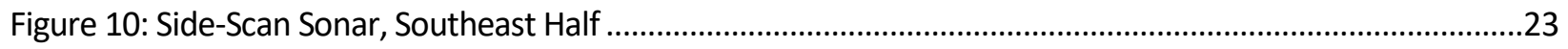

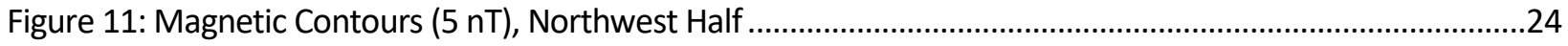

Figure 12: Magnetic Contours (5 nT), Southeast Half ...................................................................................25

\section{List of Tables}

Page

Table 1: Wrecks Reported Within Three Miles of Survey Area ........................................................................9

Table 2: Previous Investigations Within Three Miles of the Survey Area ...........................................................10 


\section{Abstract}

BOB Hydrographics, LLC conducted a marine geophysical survey and archaeological assessment of a proposed construction access channel in Galveston County, on behalf of HDR Engineering, Inc. A proposed 25-acre bay access channel would cross portions of State Mineral Lease Tracts, West Bay 59, 65 and 66 in West Galveston Bay. The channel would provide construction access to build a breakwater for the Galveston Island State Park Marsh Protection and Restoration Project, sponsored by the General Land Office. An archaeological survey was requested by the U.S. Army Corps of Engineers, Galveston District, based on their review of Permit Application SWG-1998-02298. Consultation between the Texas Historical Commission and the Galveston District concluded that archaeological survey only would be required for the channel providing access from the bay to the island and not for areas adjacent and including the proposed breakwaters. The area of potential effect encompasses 70 acres, including a 50-meter buffer mandated by the Texas Historical Commission around the proposed channel. A review of cultural background determined that 1 marine archaeological investigation and, at least, 1 wreck have been reported within 3 miles of the survey area.

BOB completed a marine geophysical survey on May 9, 2019 under Texas Antiquities Permit 8906. A total of 140 acres was surveyed to provide options for adjusting the route if necessary. Water depth at the time of the survey ranged from 4 to 9 feet. $\mathrm{BOB}$ assessed all geophysical data to locate archaeological sites potentially affected by construction of the access channel. No artifacts were collected during the survey. No significant geophysical targets were discovered that might be potentially eligible for the State Antiquities Landmark or for the National Register of Historic Places. BOB recommends cultural resource clearance for all areas surveyed, provided that a THC-mandated 50-meter buffer is honored around the perimeter of the survey area.

This study was completed in compliance with Section 106 of the National Historic Preservation Act (Public Law 89-665; 16 U.S.C. 470) and the Antiquities Code of Texas (Texas Natural Resource Code, Title 9, Chapter 191). The minimum reporting and survey requirements for marine archaeological studies conducted under a Texas Antiquities Permit are mandated by The Texas Administrative Code, Title 13, Part 2, Chapters 26 and 28, respectively. Project records are curated at the Center for Archaeological Studies at Texas State University in San Marcos. 


\section{Introduction}

BOB Hydrographics, LLC (BOB) conducted a marine geophysical survey and archaeological assessment of a proposed construction access channel in Galveston County (Figure 1) on behalf of HDR Engineering, Inc. A proposed 25-acre bay access channel would cross portions of State Mineral Lease Tracts, West Bay 59, 65 and 66 in West Galveston Bay. The channel would provide construction access to build a breakwater for the Galveston Island State Park Marsh Protection and Restoration Project, sponsored by the General Land Office. An archaeological survey was requested by the U.S. Army Corps of Engineers, Galveston District, based on their review of Permit Application SWG-1998-02298. Consultation between the Texas Historical Commission (THC) and the Galveston District concluded that archaeological survey only would be required for the channel providing access from the bay to the island and not for areas adjacent and including the proposed breakwaters. The area of potential effect (APE) encompasses 70 acres, including a 50-meter $(\mathrm{m})$ buffer mandated by the THC around the proposed channel. A review of cultural background determined that 1 marine archaeological investigation and, at least, 1 wreck have been reported within 3 miles of the survey area.

BOB completed a marine geophysical survey on May 9, 2019 under Texas Antiquities Permit 8906. The survey was performed by the archaeological Principal Investigator, Robert Gearhart, with assistance from Ed Baxter of Baxter Consulting. The Principal Investigator was solely responsible for archaeological data analysis and report preparation. A total of 140 acres was surveyed to provide options for adjusting the route if necessary. Water depth at the time of the survey ranged from 4 to 9 feet. BOB assessed all geophysical data to locate submerged archaeological sites potentially affected by construction of the access channel. Submerged archaeological sites, in this context, might be sunken or abandoned watercraft eligible for nomination to the National Register of Historic Places (NRHP) or as State Antiquities Landmarks. No artifacts were collected during the survey. No significant geophysical targets were discovered that might be potentially eligible for the State Antiquities Landmark or for the NRHP. BOB recommends cultural resource clearance for all areas surveyed, provided that a THC-mandated 50-m buffer is honored around the perimeter of the survey area.

This study was completed in compliance with Section 106 of the National Historic Preservation Act (Public Law 89-665; 16 U.S.C. 470), requiring that the lead agency consider the effects of projects, receiving either permits or funding from the federal government Resource, upon historic resources. This study also complies with the Antiquities Code of Texas (Texas Natural Code, Title 9, Chapter 191), which provides for the protection of cultural resources on state lands. The survey area is publicly owned; therefore, a Texas Antiquities Permit was obtained prior to beginning fieldwork. Title 13, Part 2, Chapters 26 and 28 of The Texas Administrative Code mandates the minimum reporting and survey requirements, respectively, for marine archaeological studies conducted under Texas Antiquities Permits. Project records are curated at the Center for Archaeological Studies at Texas State University in San Marcos.

This report is organized into six sections that provide context for interpreting the survey results and includes maps of magnetic contours and side-scan sonar imagery. Section II relies upon a combination of published literature and data collected by this survey to summarize the physical environment of the 


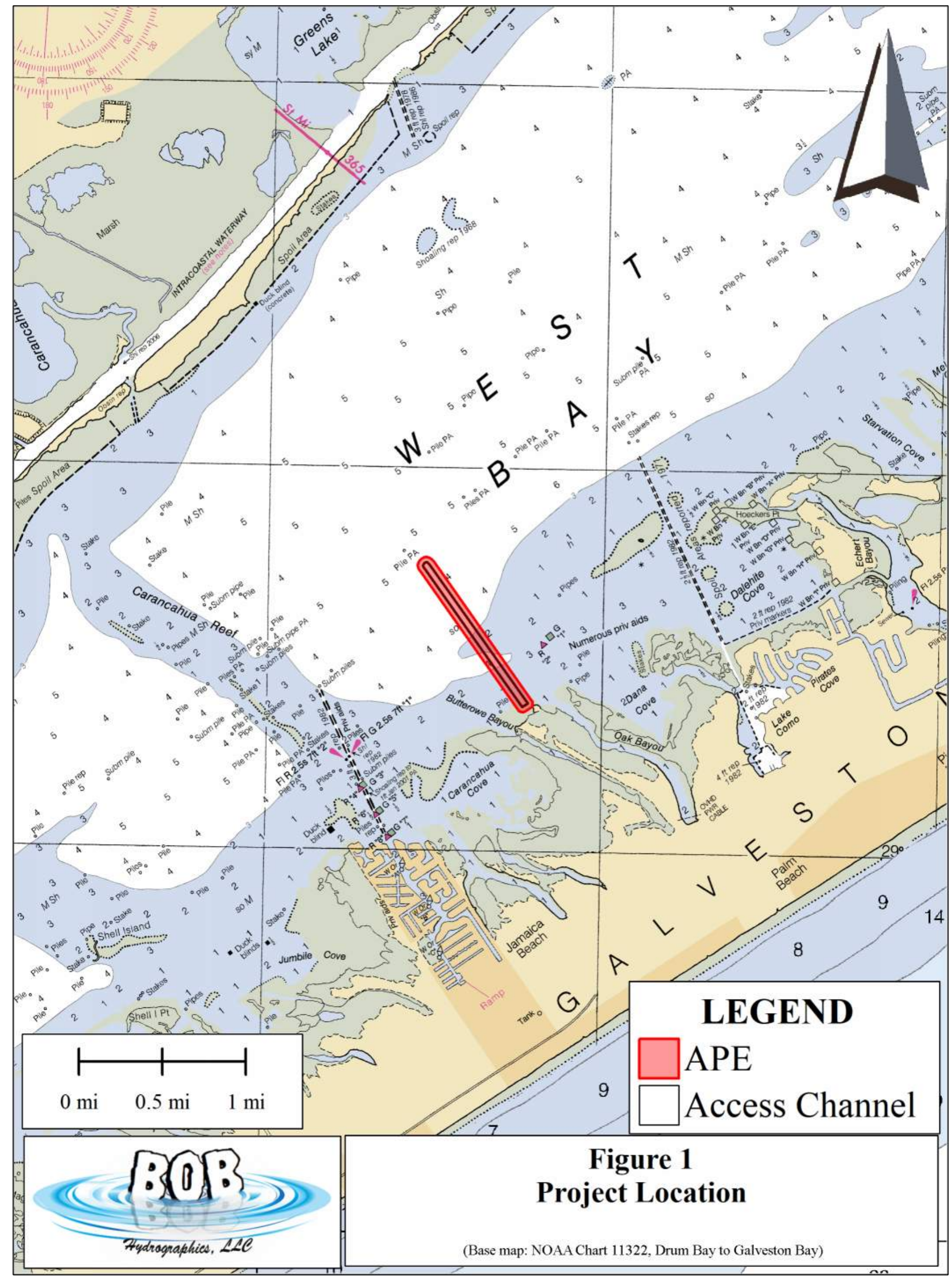


survey area. Section III summarizes the relevant cultural background within a 3-mile radius of the survey area, including maritime history, previous archaeological investigations, and the potential for intact archaeological sites. Section IV summarizes methods for conducting the survey and for processing and analyzing the geophysical data. Section $\mathrm{V}$ presents an archaeological assessment of the geophysical data and provides recommendations specific to archaeological findings within the survey area. Bibliographic references cited in the text are included as Section VI.

\section{Physical Environment}

Figure 2 shows the landscape of 1918 prior to any significant change of historic water depths. The bathymetry (Mean Low Water) shown for the APE in Figure 2 dates from 1917 (United States Coast and Geodetic Survey 1918). By contrast, modern bathymetry of the APE is charted 1-2 feet (ft) deeper (Mean Lower Low Water) on the most recent version of the National Oceanic and Atmospheric Administration's (NOAA) Electronic Navigation Chart 11322. Water depth during the survey (Figure 3) was significantly deeper than charted owing to a particularly high tide that was even with the top of residential docks in the Jamaica Beach subdivision. The West Bay reach of the Brazos-Galveston Canal is charted as $5 \mathrm{ft}$ deep and about 1,000 ft north of the APE in 1917.

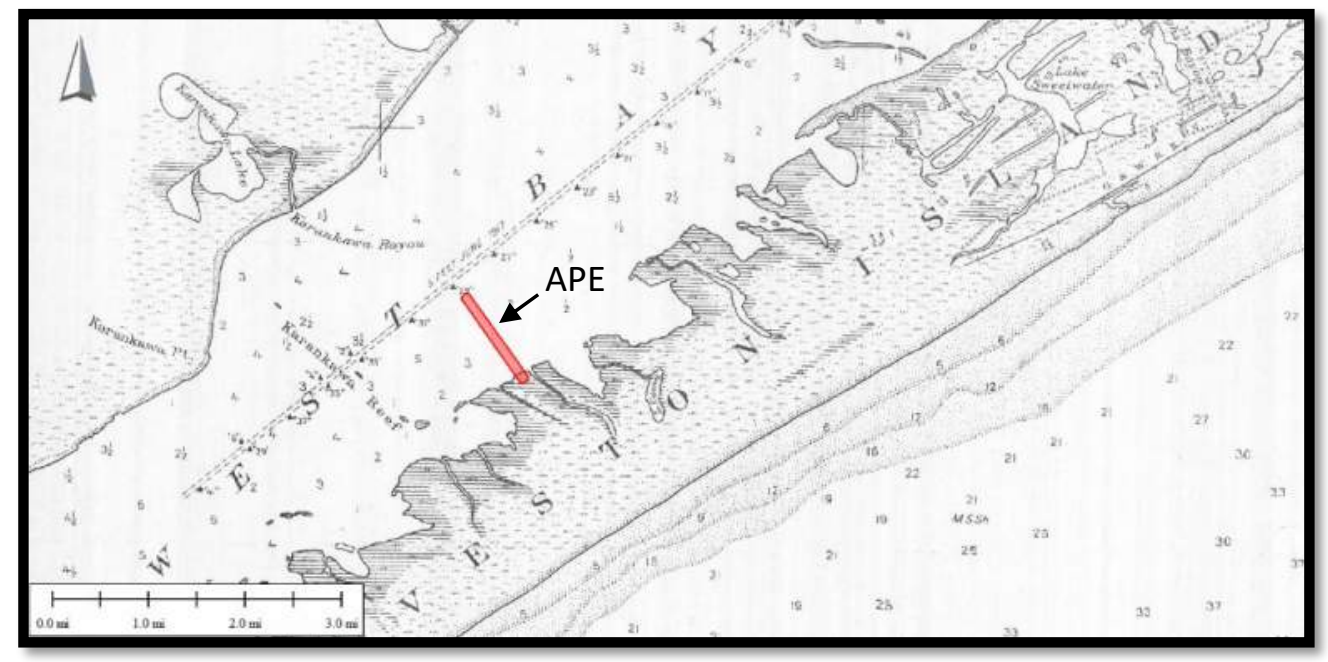

Figure 2: APE in 1918 (United States Coast and Geodetic Survey 1918)

Stranding in shoal water during a severe weather event is the most likely source of shipping losses in the survey area. The central Texas Coast can experience hazardous weather conditions throughout much of the year. Hurricane season lasts from late June through October. Hurricane-force winds can devastate ships caught unprepared. During the winter, severe cold fronts affect the Texas Coast. These "Northers" may have winds exceeding 50 miles per hour, generating dangerous waves, and can last 24-36 hours (McGowen 1976:19-23, 94). There are no naturally-occurring reefs in the survey area, but stranding could have occurred anywhere, depending on the draft of the vessel and the height of the storm surge. Stranding would be more likely near the island than in the middle of West Bay. Natural depths toward the middle of the bay were not substantially less than the depth of the Brazos-Galveston Canal, thus deeper portions of the APE likely were navigable by most vessels traveling through the area. 


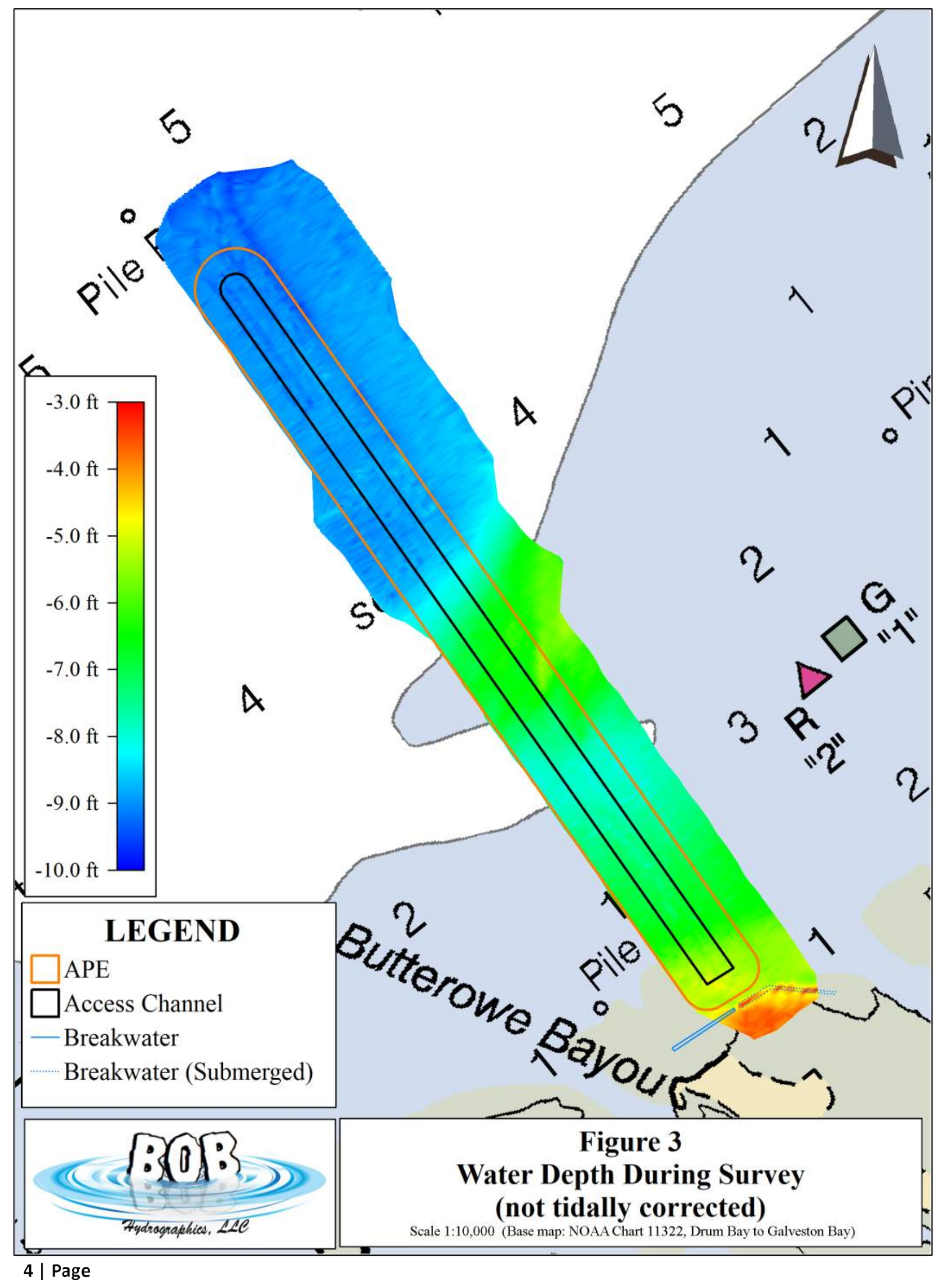




\section{Cultural Background}

\section{Maritime History}

Spanish claims to the Galveston area began in 1519, when a Spaniard named Alonso Alvarez de Piñeda led an expedition, on behalf of the governor of Jamaica, to map lands bordering the Gulf of Mexico. Piñeda produced the earliest known map of the Gulf of Mexico showing major inlets along its coast. There is no reliable evidence that he explored inland of the Texas Coast, but, at the least, he demonstrated there was no shortcut to Asia through the Gulf of Mexico (Chipman and Joseph 2010: 24-25).

The first Europeans known to explore the Texas Coast inland were survivors from the shipwrecked Pánfilo de Narváez expedition of 1527. Álvar Núñez Cabeza de Vaca and 80 other Spaniards sailed on rafts to what many believe was Galveston Island. Those who survived the first winter were enslaved by Native Americans. Only four men returned to tell their stories of wandering from tribe to tribe through what is now Texas and northern Mexico to the Pacific Coast, eventually reaching Mexico City after eight years. Cabeza de Vaca published his story in 1542 upon returning to Spain (e.g., Cabeza de Vaca 2013).

In 1539, Hernando de Soto led the first extensive European expedition through what is now the southeastern United States. Soto had hopes of finding gold and silver to match that of Central and South America. Instead, he died of a fever after three years of fruitless search, handing over leadership of the expedition to Luis de Moscoso Alvarado shortly before his death. Moscoso led the remnants of Soto's expedition, over 300 men, down the Mississippi River in 1543 and sailed along the Gulf Coast in seven makeshift boats to Pánuco. The Soto expedition lost half of its men, failed to find any precious metals, and blazed a path of violence and disease through native populations. Its main accomplishment was expanding Spain's territorial claims in North America (Chipman and Joseph 2010:36-43; Weddle 1991:100).

The Spanish silver fleet, sailing out of Veracruz, conducted steady trade with Havana from the midsixteenth century until 1790 . Their ships typically followed either a northern route, paralleling the coast, or crossed the central Gulf of Mexico. Seasonal changes in wind and current patterns determined their choice of routes (Lugo-Fernandez et al. 2007). The northern route occasionally imperiled Spanish flotillas when storms pushed them toward the coast. In 1554 a fleet of three Spanish ships wrecked on the Texas Coast about 70 miles south of Mustang Island. Another Spanish ship from Veracruz, El Nuevo Constante, wrecked near the Louisiana Coast, about 75 miles east of Sabine Pass, in 1766 (Pearson and Hoffman 1995).

Loss of the 1554-fleet, including Santa María de Yciar, San Esteban, and Espíritu Santo, led in the short term to an intensive 2-month salvage effort by García de Escalante Alvarado to recover their valuable cargos (McDonald and Arnold 1979). The loss of nearly $300 \mathrm{crew}$ and passengers (only 32 people returned to Veracruz), including women and children, prompted longer range plans for more detailed explorations

of the Gulf Coast. Guido de Lavazares was chosen to lead an expedition of three ships with orders to explore the entire coast from Rio de las Palmas to the Florida Keys.

Lavazares arrived on the Texas Coast in the fall of 1558 at the latitude of present-day Kingsville (Chipman and Joseph 2010: 48). From that point, he followed the coast, stopping in what is believed to be 
Matagorda Bay, where he formally claimed the region as a Spanish possession (Chipman and Joseph 2010:48 and Weddle 1991:100-103). Lavazares continued clockwise along the coast until contrary winds, east of Mobile Bay, forced his return to Veracruz. A second expedition by Gonzalo Gayon followed the Gulf Coast in the opposite direction, from Florida to Texas, within a year or two of Lavazares.

The voyages of Lavazares and Gayon retraced Piñeda's path from four decades earlier and reinforced Spain's claim to the Gulf Coast. Nevertheless, while Spain claimed a vast territory, their population and trade centers were located far to the south and west. The Spanish crown did little to promote exploration or settlement along the northern Gulf Coast, instead focusing on inland expeditions and establishment of missions to Christianize the natives. Ultimately Spain's territory in Texas and the Southeast proved too large and isolated to sustain. It was not until France began to encroach in the region that Spain attempted to reassert control.

In 1682, a French expedition, led by René Robert Cavelier, Sieur de La Salle, traveled down the length of the Mississippi River to its mouth, claiming the Louisiana Territory on behalf of King Louis XIV and France. La Salle was partially following in the footsteps of the Spaniard Moscoso down the lower Mississippi, albeit in a much more deliberative manner. The French territorial claim established by La Salle extended to much of what later became the Louisiana Purchase. La Salle returned to the Gulf Coast by ship in 1685 intent on establishing a permanent colony near the mouth of the Mississippi River. Unfortunately for La Salle and his 300 colonists, they missed the Mississippi River and arrived, instead, at Matagorda Bay on the Texas Coast.

By 1686 when Spain heard rumors of a French colony in the heart of their territory, La Salle's Fort St. Louis was already doomed to failure. The expedition lost one of three ships upon their arrival. A second ship soon returned to France with a group of colonists, including La Salle's engineer, Minet, who took with him the first map of Matagorda Bay. Their last ship, La Belle, grounded during a storm in early 1686 and was lost in Matagorda Bay while La Salle was away on an overland expedition, attempting to relocate the Mississippi River. La Salle was murdered by his own men, in a subsequent overland voyage about a year later on March 19, 1687. The location of La Salle's murder likely was between the Navasota and Trinity Rivers in modern Madison or Walker County (Weddle 2001: 214-234). Those colonists remaining at Fort St. Louis, having no way to return to Europe, eventually perished.

Spain mounted an intensive exploration of the Texas Coast to find and rout out the unwelcome intruders while simultaneously charting their own, relatively unknown, possessions there. Weddle (1991:68) summarized the effect of La Salle's arrival on the Spanish royal court as inspiring "the most intense coastal reconnaissance ever made in the Gulf of Mexico. In five coastal voyages spanning three years, there were few rivers and bays that had not been examined."

An expedition led by Martín de Rivas and Pedro de Iriarte departed Veracruz on December 25, 1686 in search of La Salle. They sailed clockwise along the Gulf Coast with instructions to sail only by day, keep within sight of land, and enter all bays and rivers until they reached the supposed latitude of the reputed Espíritu Santo Bay or the Mississippi River. Along the way, on April 3, 1687, they discovered wreckage of a French ship (La Belle) in Matagorda Bay, which they correctly presumed to have belonged to La Salle. 
Unknown to Rivas and Iriarte, La Salle had died two weeks before their discovery, and the remnants of his colony were clinging to life only a few miles upstream from them. Alonso de León finally discovered the abandoned remains of Fort St. Louis in 1689 upstream from Lavaca Bay on Garcitas Creek (Weddle 1991: 52-70).

Rivas and Iriarte continued on their expedition, after discovering La Belle, to rule out other locations along the northern Gulf Coast and to find the River "Micipipi" on which the French reportedly were intent upon establishing a settlement. They entered San Luis Pass, which they called Santa Suzana, in mid-April. Continuing along the coast, they encountered the main mouth of Galveston Bay. Discouraged by shoals, they spent little time exploring but returned on April 25 for a closer inspection. They sailed inland to a point of land believed to be Eagle Point but found no evidence of prior European visitors (Weddle 1991: 52-70).

La Salle's expedition ended in failure, but his influence reached far into the future. The boundary between Louisiana and Texas remained contentious and shifting for the next century and a half. Spain responded to the French incursion by establishing a network of missions, presidios and settlements in East Texas and Louisiana, 100 to 200 miles upstream from the coast, on the Neches, Sabine and Red rivers, through the first quarter of the eighteenth century (Chipman and Joseph 2010: 106-107).

Jean Baptiste Bénard de La Harpe produced the earliest detailed map of Galveston Bay in 1721. La Harpe intended to reestablish La Salle's abandoned fort, but he unknowingly arrived at the wrong bay. While in Galveston Bay, La Harpe met a French sailer named Francois Simars de Bellisle, an officer from a French ship, Maréchal d'Estrée, that stranded near the entrance to Galveston Bay in 1719 (Folmer 1940). The ship was later floated, but Bellisle and a small group of officers elected to stay behind. He was the sole survivor the group. Bellisle was a slave to Native Americans for over a year during which time he wandered Coastal Texas from Galveston Bay to Fort Saint-Jean-Baptiste at present-day Natchitoches, Louisiana (Folmer 1940).

Galveston was settled soon after the Louisiana Purchase of 1803. Privateers based their operations on Galveston Island and Point Bolivar, supported by French, Mexican and Anglo-American interests seeking to overturn Spanish control of the region. Louis-Michel Aury operated from Galveston Island beginning in 1816 during the Mexican War for Independence. Aury, with the support of Mexicans in New Orleans, organized Galveston's first government, declared the town an official port of the Mexican Republic, and began raiding Spanish shipping. Within a year, Aury led an attack in Mexico with over 700 troops. While he was in Mexico, Jean Lafitte took over Aury's Galveston fort. James Long declared a Texas Republic in 1819 and installed Lafitte as governor of the island. Lafitte was forced from the island in 1821 when the U.S. government enforced a policy against piracy in the Gulf of Mexico (Davis 2005:419-420).

In 1824, Stephen F. Austin encouraged the newly independent Mexican government to settle Galveston in order to facilitate the shipment of cotton to England. The Congress of Mexico established a port of customs at Galveston in 1825 (Cotham 1998:1; Francaviglia 1998:91, 95). Galveston was incorporated as a city late in 1836 after Texas won independence from Mexico, and within two years, Galveston became the largest source of cotton shipped to the East Coast and Europe. Houston was founded that same year 
on the banks of Buffalo Bayou several miles upstream from Galveston Bay. When the Civil War began, Galveston was the second largest city in Texas, and by 1870 it was the largest (Cotham 1998:184).

West Galveston Bay was recognized early in the history of Anglo-American settlement as an important route between Brazos River plantations and the port of Galveston, but navigation was hindered by numerous reefs and shoals. The earliest Brazos Canal was a privately-funded effort in the 1840s, but it was never fully completed (Myers 1998; cited in Hoyt, et al. 1999: 28). The State of Texas chartered the Galveston and Brazos Navigation Company in 1850 to construct the Galveston-Brazos Canal from the Brazos River to West Galveston Bay. The work was completed in the mid-19th century (Hole 1982: 7-9; cited in Hoyt, et al. 1999: 28). The Galveston-Brazos Canal ran through the central part of West Galveston Bay and would have passed near the north end of the access channel proposed for this project. Initially the West Bay reach of the canal was not improved except where it passed through reefs. For example, a chart of Galveston Island defenses (Unidentified c. 1865) shows a portion of this canal, labeled "Dugout Channel for Inland Navigation," running between the Deer Islands, about 5 miles northeast of the APE. That same chart shows an interesting but unrelated feature; a ferry route, about 3.5 miles northeast of the APE, connected wharves on either side of West Galveston Bay. Multiple dredging projects were financed between 1850 and the 1930 s to improve and maintain the canal across West Bay. Then, during the 1930s and 1940s, the route was moved to the north side of West Bay as part of the modern Gulf Intracoastal Waterway (Alperin 1977).

Channel improvements coincided with steady advancements in the safety of ships during the first half of the twentieth century. Sailing vessels were being replaced rapidly by safer, machine-powered vessels. By 1910, sailing ships comprised less than half of annual losses of U.S. merchant vessels for the first time, and by the end of World War II, only 2-percent of nationwide losses were sailing ships. This is significant, because sailing ships were at a higher risk of running aground than machine-powered vessels. At the same time that machinery was replacing wind power, more durable metal hulls gradually were replacing wooden hulls, a trend which had accelerated by the turn of the century. Nevertheless, at least 93 percent of all U.S. merchant vessels lost through the end of World War II were made of wood (Gearhart 2011a).

\section{Potential for Historic Shipwrecks}

Europeans have navigated the Texas Coast, including the area offshore of Galveston Island, for the past 500 years, beginning with Piñeda's expedition in 1519. The earliest European arrivals to Galveston Island were Cabeza de Vaca and other survivors of the 1527 Narváez expedition. Rivas and Iriarte briefly entered Galveston Bay in 1687 during their search for La Salle's settlement. The bay was first mapped in 1721 by La Harpe. Galveston Island was settled following the Louisiana Purchase of 1803, and Bolivar Roads became a center of privateer operations for a brief time in the early nineteenth century. The city of Galveston was incorporated in 1836 following Texas Independence and quickly became the largest cotton port on the continent. By 1870 the city had grown to be the largest city in Texas. Houston eclipsed Galveston following the creation of the Houston Ship Channel and the destruction of Galveston by a hurricane in 1906. West Galveston Bay has been an important route for commercial navigation between the Brazos River and the Port of Galveston since the 1840s. The growth of the petroleum industry since the early twentieth century has far surpassed cotton as the most important economic engine of the region. Today Galveston Bay and its tributaries are home to the fifth largest metropolitan area in the United States, and the Port of Houston, alone, is the nation's second-busiest port by overall tonnage. 
Shipwrecks reported within 3 miles of the survey area are included in Table 1. Sources consulted for Table 1 include the THC's Texas Archaeological Sites Atlas (Atlas); NOAA's Automated Wreck and Obstruction Information System (AWOIS) database; a shipwreck database compiled by PBS\&J; and historic maps from the Texas Historical Overlay (Foster, et al. 2006). There also is potential for unreported wrecks dating back to the time of early European navigation through the area.

The THC Atlas contains reports of shipwrecks from historic records. The AWOIS database is maintained by NOAA to support the charting of coastal areas. AWOIS tends to report recent shipwrecks; however, historic wrecks are included. Positions for wrecks in AWOIS are usually more accurate than those from historic records, although positions pre-dating the era of satellite position systems can vary considerably from actual locations. A group of archaeologists, including this author, assembled the PBS\&J database, in part, based on information gathered from charts, historical reports, THC files, and AWOIS. The PBS\&J database focuses primarily on well-documented commercial wrecks postdating 1850.

At least 1 shipwreck has been reported within a 3-mile radius of the Survey Area (Table 1) by one or more of the sources listed above. Positions reported in historical accounts are often imprecise, and archaeologists have yet to record any of the wrecks listed in Table 1.

Table 1: Wrecks Reported Within Three Miles of Survey Area

\begin{tabular}{ccccc}
$\begin{array}{c}\text { Name of } \\
\text { Vessel }\end{array}$ & $\begin{array}{c}\text { THC } \\
\text { No. }\end{array}$ & Description & $\begin{array}{c}\text { Date } \\
\text { Lost }\end{array}$ & $\begin{array}{c}\text { Position } \\
\text { Accuracy }\end{array}$ \\
\hline $\begin{array}{l}\text { Samuel M. } \\
\text { Williams }\end{array}$ & 970 & Merchant sail-steam vessel & 1849 & unknown \\
\hline
\end{tabular}

\section{Factors Affecting Vessel Loss}

Factors contributing to the loss of watercraft vary depending on environment conditions. Historic government statistics, summarized by Gearhart, et al. (1990: Volume IV, 59-61), categorized vessel casualties, including most accidents and incidents resulting in injury or loss of property, and reported the value of losses incurred. A total loss was reported if the hull could not be saved. These statistics do not reflect the degree to which cargo and vessels were salvaged. Types of casualties included foundering, stranding, collision and other (fires, boiler explosions, injuries, mechanical failures, etc.). Severe weather accounted for 55 percent of total losses reported by the U.S. Lifesaving Service from 1876 through 1914. Almost half of all losses from foundering were caused by weather, compared with two thirds of losses from stranding. Mariners had short warning of approaching storms prior to modern weather forecasting.

Foundering was the primary mechanism of vessel loss in navigable waters. The Annual List of Merchant Vessels of the United States (United States Department of the Treasury 1906-1946) defined foundering as leaking or capsizing of vessels. Foundering accounted for about 6 percent of historic vessel losses. Despite its low rate of occurrence, recovery from foundering was less likely than from any other type of casualty. Fifty-four percent of all foundered vessels were reported as totally lost.

Stranding was the primary mechanism of loss in shoal waters and was, by far, the most common type of shipwreck during the historic period. Stranding (or grounding) accounted for 64 percent of total losses 
reported by the U.S. Lifesaving Service for the period 1876 through 1914 (Gearhart, et al. 1990: Volume IV, 59-61). Stranding occurred where the water was too shallow for navigation, including shorelines, harbor bars and reefs. Forty-six percent of stranding events resulted in a total loss (Gearhart 1990: Volume IV, 59-61). Stranding is the most likely source of shipping losses in the survey area.

\section{Factors Affecting Vessel Preservation}

Preservation of sunken watercraft depends mainly upon their composition and the extent of their burial in the seafloor. Vessels may become partially buried soon after sinking due to the combined effects of storm-induced current scour, liquefaction of sediments, and the ship's weight pressing down on a waterlogged substrate. Ships made of metal are equally susceptible to burial as wooden hulls, but metal hulls remain exposed much longer than wooden ones in saline waters along the Texas Coast. Exposed wooden components tend to disintegrate quickly where wood-boring organisms thrive. Biological organisms and water saturation weaken the wood, which is then more easily disarticulated and laid flat or removed by fishing trawlers and storm waves. Burial promotes long-term preservation of wood by creating an oxygen-deprived environment, which limits biological activity. Given a sufficient quantity of weakly-consolidated sediment, a significant portion of a hull might become preserved in this manner.

Iron corrodes five times faster in seawater than when buried on land. Iron artifacts tend to become concreted when calcium carbonate from the seawater cements adjacent materials, such as rock and sand, or even other artifacts, to the iron object. Prolonged oxidation can leach out most or all iron mineral, leaving only a carbonate mold of the original artifact (Hamilton 2010). Iron and steel hulls, nevertheless, can survive seawater exposure for well over a century.

\section{Previous Investigations}

One marine archaeological survey has been completed within 3 miles of the survey area (Table 2). An abstract for the study is available on the THC Atlas.

Table 2: Previous Investigations Within Three Miles of the Survey Area

\begin{tabular}{llll}
$\begin{array}{l}\text { Antiquities } \\
\text { Permit }\end{array}$ & $\begin{array}{l}\text { Principal } \\
\text { Investigator }\end{array}$ & Report Title & Contractor \\
\hline $\mathbf{1 0 5 0}$ & Robert Gearhart & $\begin{array}{l}\text { A Survey and Assessment of Cultural Resources } \\
\text { at Eckert Bayou, Galveston County, Texas }\end{array}$ & $\begin{array}{l}\text { Espey, Huston \& } \\
\text { Associates, Inc. }\end{array}$ \\
\hline
\end{tabular}

Espey, Huston \& Associates, Inc. performed terrestrial and marine survey in 1990 at Eckert Bayou on Galveston Island (Foster and Gearhart 1991). Their study was located about 2 miles west of the present survey area. A previously reported prehistoric site, 41GV66, was reexamined as part of their survey. Aboriginal ceramics from the site were located during the terrestrial survey both on the shore surface and within shovel tests. A nautical survey, conducted in a small portion of Eckert Bayou, revealed three magnetic anomalies, all of which were inspected. None of the anomalies were deemed historically significant. No State Antiquities Landmark or NRHP eligible deposits were discovered within the study area and no further investigations were recommended. 


\section{Research Design}

\section{Survey Methods}

The purpose of the survey was to map geophysical anomalies that might have historical significance. In the context of submerged lands, historical significance typically, although not necessarily, refers to association with historic shipwrecks. The primary instrument for locating potential shipwrecks in buried contexts is the magnetometer. Exposed shipwrecks are visible in side-scan sonar imagery; however, historic wrecks in Texas bays and shallow areas in the Gulf of Mexico are more often buried. Vessels predating World War II tend to be constructed of wood, which quickly deteriorates when exposed to wood-loving organisms common to warm saline environments. Nevertheless, buried portions of wooden hulls can retain a high level of artifact preservation and historic integrity. Wrecks exposed above the mudline for more than a few years tend to be constructed of materials other than wood.

Geophysical investigations were designed to meet or exceed the following minimum standards of the THC for archaeological survey of state-owned submerged lands (Texas Administrative Code, Title 13, Part 2, Chapter 28, Rule 28.6): 1) the survey must be conducted under a Texas Antiquities Permit issued by the THC; 2 ) the survey line interval cannot exceed $20 \mathrm{~m}$ (30 m when greater than 3 nautical miles offshore); 3) bottom-disturbing activities must be avoided within $50 \mathrm{~m}$ of potentially significant targets ( $150 \mathrm{~m}$ when more than 3 nautical miles offshore); 3) the survey area must extend beyond the limits of bottomdisturbing activities by the width of the avoidance margin; 4) survey instrumentation must include a marine magnetometer, a high-resolution side-scan sonar, and a recording fathometer all of which must record data digitally to electronic storage media; 5) survey instrumentation should be interfaced with a positioning system having accuracy comparable or better than a differential global positioning system (GPS) receiver; 6) the magnetometer must be towed within $6 \mathrm{~m}$ of the marine bed and should sample at least once per second; 7) the side-scan sonar should operate at a minimum frequency of 300 kiloHertz $(\mathrm{kHz}) ; 8)$ the positioning system should sample at least once per second; and 9) no artifact collection is permitted.

Geophysical survey was completed on May 9, 2019 by the archaeological Principal Investigator, Robert Gearhart, with assistance from Ed Baxter of Baxter Consulting. The Principal Investigator was solely responsible for archaeological data analysis and report preparation. The survey was conducted from BOB's 20-ft survey boat. Primary transects were spaced $20 \mathrm{~m}$ apart. Additional transects were surveyed over most anomalies at a closer interval of $10 \mathrm{~m}$ or less. Anomalies were not selected for close-order survey based on resemblance to significance criteria, as normally done, because the primary survey data had not been processed at the time. Instead, an attempt was made to collect additional data over all anomalies to take advantage of a weather window that was anticipated to close by the following day.

Vector data, including sensor positions, water depth, and magnetometer, were logged in Hypack navigation software. Raster data, including side-scan sonar, were logged in Edgetech's Discover software. Geographic positions were acquired using a Trimble SPS785, GPS system. Single-beam bathymetry data were acquired using a Teledyne-Odom CV-100 recording fathometer equipped with a 200-kHz transducer. A Geometrics 882 magnetometer was towed on the surface $62 \mathrm{ft}$ behind the boat. Side-scan sonar data was acquired using a $600-\mathrm{kHz}$, Edgetech 4125 system, towed from the starboard side of the boat.

11 | P a g e 
Horizontal position estimates for each sensor were recorded in real time. Sonar imagery was recorded using Edgetech's Discover acquisition software. Geographic positions were embedded in the digital sonar data as it was recorded. Sonar data was recorded along a $25-\mathrm{m}$-wide (82-ft) swath overlapping with data from adjacent vessel tracks. Chesapeake SonarWiz software was used to combine sonar data from each transect into a composite sonar mosaic.

\section{Interpretation of Magnetometer Data}

Low-frequency fluctuations in magnetic data caused, for example, by diurnal passage of the sun or by geologic gradients were removed, prior to contouring, using a filter algorithm. The algorithm treats shortterm fluctuations, exceeding a selected amplitude threshold (typically 0.5 nanoTesla [nT]), as anomalous values. The result is a dataset in which abnormally high and low magnetic amplitudes (anomalies) are centered around zero (representing the ambient level). All amplitude shifts, smaller than the threshold value, are reduced to near zero and are treated as ambient background. This process removes low frequency data, leaving potentially significant anomalies intact, and allows a visual representation of anomaly polarity.

Magnetometer data illustrated in this report have been thinned to a 1-second interval between data points. Diurnally-corrected magnetometer data was contoured using Blue Marble's Global Mapper software (Version 17.2) at a 5-nT contour interval. Magnetic amplitudes between $+5 \mathrm{nT}$ and $-5 \mathrm{nT}$ are considered insignificant. Contour maps omit the 0-nT contour level to prevent a cluttered appearance. Positive amplitude is indicated by red contours, and negative amplitude is drawn as blue contours.

Most magnetic anomalies in marine environments are caused by relatively small pieces of ferromagnetic debris, which tend to concentrate near high-traffic areas, marine disposal areas, industrial developments, petroleum wells, and pipelines. Ferromagnetic debris far outnumbers shipwrecks, necessitating some means for distinguishing between the two when conducting archaeological assessments. Archaeologists have interpreted magnetic anomalies using a variety of criteria over the decades since marine geophysical surveys have been used for cultural resource investigations. Various factors, including amplitude, complexity and horizontal dimensions, have been considered important when trying to distinguish shipwreck anomalies from debris (non-shipwreck) anomalies. The interpretation method used by this author considers an additional factor, orientation, as an aid to segregating potential shipwreck anomalies from debris anomalies. Each of these factors is described in more detail below. The role of side-scan sonar in aiding interpretation is also considered.

The interpretative method described below is based primarily upon studies by Gearhart $(2011 \mathrm{~b}, 2016)$ that analyzed magnetic data from a large and diverse collection of anomaly sources, including 39 verified shipwrecks and many debris sources, with the goal of characterizing significant differences between shipwreck and debris anomalies. Shipwrecks included in this sample represent a broad spectrum of material compositions, construction styles, ages, and archaeological contexts. Their hulls include construction from wood, iron, steel, and concrete. Their propulsion systems range from sail to steamdriven paddlewheels and propellers, and from oil and diesel screws to towed or pushed barges. They range in age from the mid-16th to the mid-20th century. They have been found in diverse depositional environments including harbor entrances, surf zones, beaches, marsh, oyster reefs, open bay waters, and 
the Gulf of Mexico. And this assortment of watercraft found their way to the seafloor in various ways including stranding on beaches, foundering at sea, by fire, by explosions (both accidental and intentional), and by abandonment. Some were partially demolished or salvaged after wrecking. Others remain largely untouched since the day they sank. Yet despite their many differences, they share common characteristics, which form the basis for this interpretative method.

\section{Role of Sonar Imagery}

Anomaly sources exposed at the seafloor can be detected by side-scan sonar, which may, on occasion, be useful for determining their identity. For example, a straight, narrow, linear sonar target might be interpreted as a pipe. A pipe interpretation becomes more likely if that target is situated along the central axis of a magnetic dipole. On the other hand, if that same sonar target is not associated with a magnetic anomaly, one might interpret, instead, a tree or anchor scour. More often than not, sonar targets are unreliable indicators of magnetic source identity, but sonar occasionally provides unambiguous verification. Sonar also can aid magnetic interpretations because of what it does not show. For example, a magnetic anomaly without a corresponding sonar target, in Texas coastal (saline) waters, is not likely associated with a shipwreck having either a metallic hull or a machine-powered propulsion system, except in areas of high sediment accretion.

Shipwrecks with metal hulls are usually exposed on the seafloor, thus tend to be fairly obvious on a sonar image. Gearhart (2011a) reported that 100 percent of shipwrecks discovered by BOEM-regulated geophysical surveys in shallow, Gulf of Mexico waters (less than $600 \mathrm{ft}$ deep) appear on side-scan sonar imagery $(n=74)$. About one third of that number are confirmed to have metal hulls. The rest are presumed to be metallic, simply because their ship-shaped structures are preserved in the water column. By comparison, only 7 wood-hulled wrecks were known to BOEM from the same area up to that time, but none of those were discovered by geophysical surveys, despite the fact that wood-hulled wrecks in the U.S., pre-dating World War II, are 13 times more abundant than metal-hulled wrecks (Gearhart 2011a). Wrecks of wood-hulled sailing ships, in Texas bays and adjacent coastal waters, are usually buried, thus they typically have no sonar target. Shipwrecks with wooden hulls and machine-powered propulsion systems might appear on sonar or might not. Lower portions of the wooden hull itself would tend to bury, but steam machinery is large and may remain exposed above the seafloor. Gas- and diesel-powered machinery tends to be smaller thus might be more easily buried than steam machinery.

\section{Amplitude}

Anomaly amplitude depends greatly upon the mass of the source and its distance from the magnetometer sensor. Small sources can produce large amplitude when measured at close range. Shipwreck anomalies from Gearhart (2011b) have average peak-to-peak amplitudes of 270 nT (range: 191-376 nT) for woodhulled sailing vessels (n=7); 5,020 nT (range: 663-15,247 nT) for wood-hulled, machine-powered vessels $(\mathrm{n}=7$ ); and 10,386 nT (range: 688-36,050 nT) for iron/steel-hulled vessels ( $\mathrm{n}=12$ ). Anomalies from verified, wood-hulled sailing vessels in Gearhart (2011b) have lower peak-to-peak amplitude than anomalies associated with either machine-powered or iron/steel-hulled vessels; however, amplitudes from machine-powered and iron/steel-hulled vessels overlap one another. Magnetic debris can produce amplitudes virtually anywhere within the range of shipwreck anomalies, thus amplitude, alone, is of little use for differentiating shipwrecks from debris. Nevertheless, amplitude may aid in anomaly interpretation 
when considered in combination with other factors. For example, a buried anomaly source with amplitude greatly exceeding the range of verified, wood-hulled shipwrecks might be more likely caused by debris, since high-amplitude shipwreck anomalies, those with iron/steel hulls or machinery, are more likely exposed on the seafloor.

\section{Complexity}

Archaeologists frequently have described shipwreck anomalies as appearing "multicomponent" or "complex", while anomalies having simple, monopolar or dipolar shapes often were attributed to debris. Garrison, et al. (1989: II, 223) summarized several common methods for prioritizing anomalies with a focus on complexity. Shipwreck anomalies were characterized as having: multiple peaks of differing magnitudes spread over an area greater than 10,000 square meters (2.5 acres); gentle gradients; and a linear association with anomalies on adjacent transects. A typical debris anomaly was characterized as having a single peak covering an area of less than 10,000 square meters, a steep gradient, and no alignment of anomalies on adjacent lines.

Some early observations of complexity in wreck anomalies pre-dated computer contouring software. One or more peaks were observed on each transect crossing a single anomaly, but the spatial relationships between those peaks were not apparent. This problem was compounded by the lower accuracy of positioning systems prior to GPS. Thus, even a simple dipole might appear more complex than it really was. Earlier magnetometer technology also might have contributed to the perception of complexity. Proton precession systems tended to produce false noise spikes in the presence of high magnetic gradients, which could be interpreted as complex patterns of amplitude peaks where none existed.

The collection of 39 anomalies from verified shipwrecks reported by Gearhart (2011b, 2016) indicate, contrary to earlier models, that shipwreck anomalies (in mid-northern latitudes) tend to be dominated by a single main dipole, oriented approximately in line with magnetic north (Figure 4, for example; also see "Orientation" below). In fact, most debris anomalies also tend toward simple, dipolar shapes, while some shipwreck anomalies have more than two amplitude peaks. The concept of complexity is insufficient, by itself, to differentiate shipwrecks from debris anomalies; although, this fact does not lessen the need to correct any remaining misconceptions that shipwreck anomalies are typically complex and debris anomalies are not. The truth is more complicated than that simple dichotomy.

Many wreck anomalies also have secondary amplitude peaks, in addition to their main, north-southaligned dipole. Secondary peaks typically have lower amplitude than the main dipole and cover a smaller area than the main dipole peaks in all examples known to this author. Secondary peaks can be caused in two ways. The combined mass of the wreck either induces secondary peaks, or they are directly associated with individual ferromagnetic sources in a debris field. 

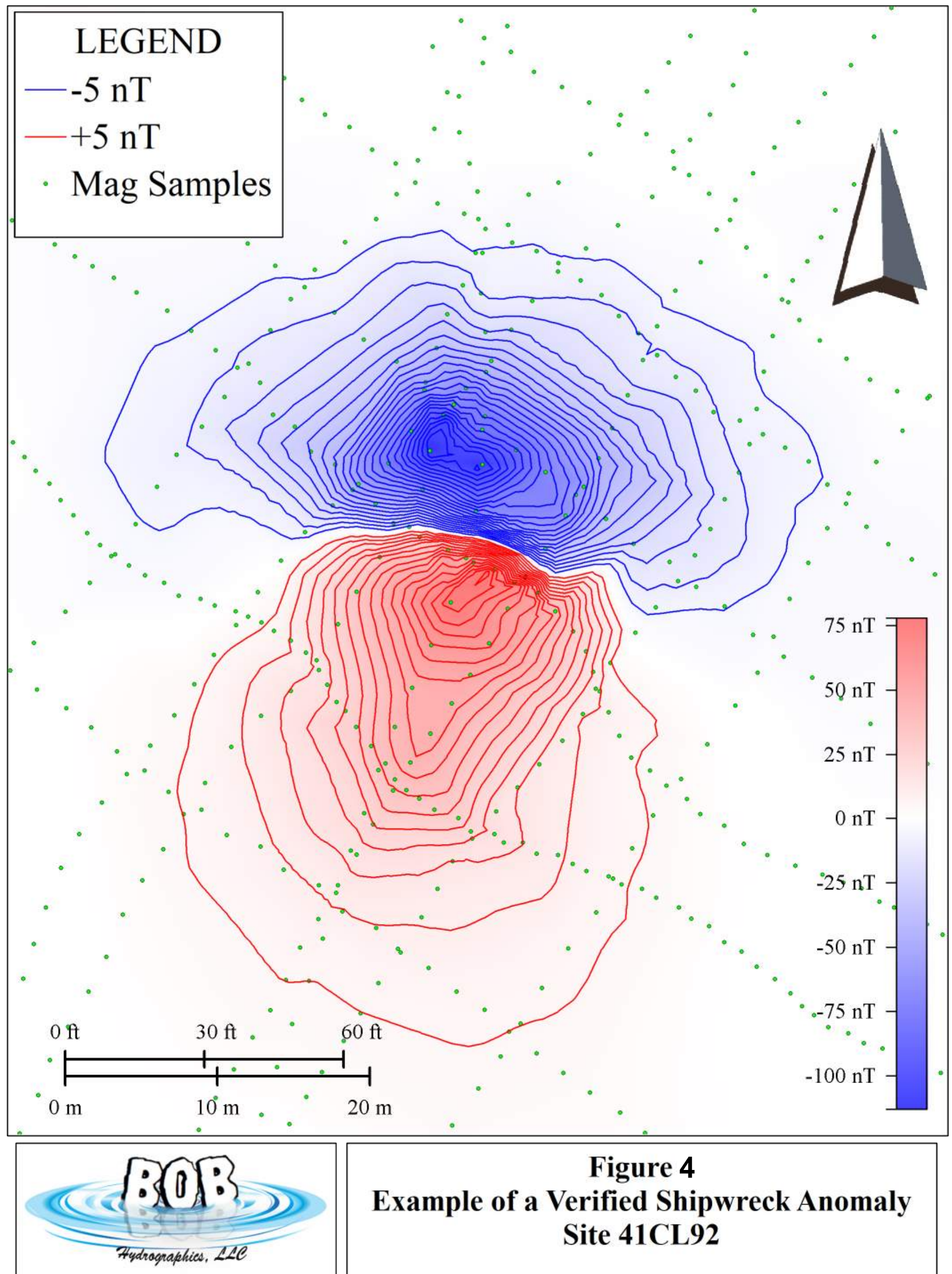

Figure 4

Example of a Verified Shipwreck Anomaly Site 41CL92 
Secondary peaks can be induced by the magnetic field lines emanating from wreckage. In mid-northern latitudes, a smaller peak sometimes occurs immediately north or south of, and in line with, the main dipole (e.g., peaks labelled " $A$ " in Figures 5, 6, and 7). Amplitude peaks of this nature are not necessarily located over an anomaly source and may not indicate the presence of widely-scattered wreckage. Rather they seem to be induced by a source of relatively high mass, such as a ferrous hull. In such cases, magnetic lines-of-force can loop so far to the north and/or south of a source that, respectively, they reinforce or diminish (i.e., are anomalous to) earth's field (Figure 6). The result is a small positive peak to the north and, occasionally, a smaller negative peak to the south of the main dipole. They will always have polarity opposite the adjoining peak of the main dipole. Such peaks are fairly symmetrical about an anomaly's north-south axis and will not overlap its main dipole. The inflection point between an induced secondary peak and the main dipole occurs where the anomaly's lines of magnetic force are perpendicular to earth's lines of force.

Other secondary peaks may be directly caused by relatively large, individual magnetic sources within or near a hull or debris field. If such a mass is sufficiently large, its anomaly might not be completely cancelled by neighboring sources, allowing it to stand out. A similar effect may be observed if a magnetometer passes sufficiently close to a complex source, such as a shipwreck, so that some large-mass sources, are individually expressed against the background of the main dipole field. Such debris-centric, secondary peaks should have fairly random orientations and positions, with respect to the main dipole, since they are directly caused by randomly-positioned objects within a debris field. They may overlie and disrupt the symmetry of the primary north-south dipole (e.g., peaks labelled "B" in Figures 5 and 7).

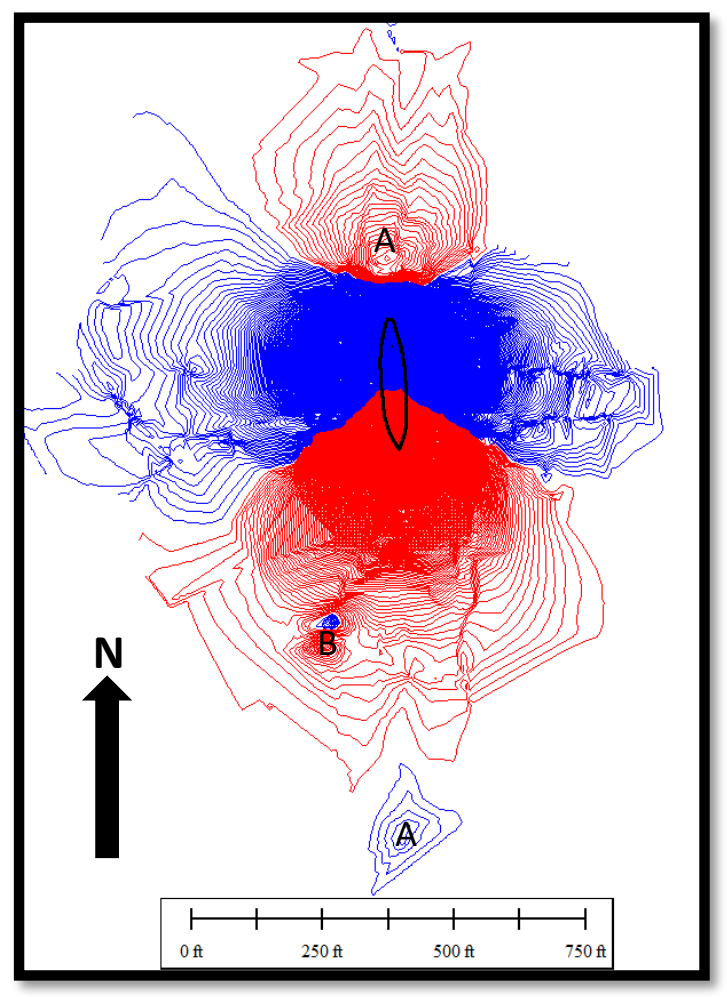

Figure 5: City of Waco Anomaly (iron hull) 5-nT contour interval

\section{Horizontal Dimensions}

Anomaly width, or duration as preferred by some, is a common and valid measure used by archaeologists for discriminating potential shipwreck anomalies from those believed more likely caused by debris. For example, Linden and Pearson (2014) would consider an anomaly significant if it has amplitude of at least $50 \mathrm{nT}$ and a width of $65 \mathrm{ft}$ or more. The horizontal dimensions of shipwreck and debris anomalies overlap considerably, especially when considering wrecks with wooden hulls, thus width alone is not particularly useful for discriminating between the two. There is a 15 -fold difference in width between the smallest wood-hulled sailing ship and the largest steel tanker, so large wrecks tend to be obvious. Unfortunately, small, wooden watercraft, even many steamboats, tend to have anomalies no wider than many debris anomalies.

Small shipwreck anomalies cannot be distinguished from debris anomalies based on size alone. All wooden-sailingship anomalies and all but one wooden-steamboat 
anomaly known to this author are smaller than 10,000 square meters, Garrison, et al.'s (1989: II, 223) minimum suggested size for typical shipwreck anomalies. Site 41CL92 (Figure 4), for example, covers an area of only 1,580 square meters ( 0.4 acres) out to the 5 -nT contour. Small, wooden, and generally historic, shipwrecks are the most difficult sites to detect precisely because their anomalies overlap in size with many debris anomalies.

The smallest wreck in Gearhart's anomaly dataset, the "Mag-13 Wreck" (Figure 8), is a wooden hull buried 2-10 ft below the seafloor. The hull measures roughly $35 \times 13 \mathrm{ft}$, based on diver probes (Gearhart 2016). The Mag-13 Wreck anomaly measures $197 \times 164 \mathrm{ft}(60 \times 50 \mathrm{~m})$ across. Site 41CL92 (Figure 4), although having larger site dimensions, has the smallest verified wreck anomaly known to this author, measuring $176 \times 155 \mathrm{ft}(53.6 \times 47.2 \mathrm{~m})$ to the 5-nT contour. Divers identified Site 41CL92 as an early 19th-century sailing vessel containing a large collection of concreted artifacts, iron bar stock, and pig iron ballast but with no hull remaining (Borgens 2004). Its debris field measures $52 \times 23 \mathrm{ft}(15.9 \times 7 \mathrm{~m})$ across.

The 41CL92 anomaly is smaller than the Mag-13 anomaly, even though the 41CL92 site dimensions are larger. Its smaller magnetic footprint might be due to its disarticulated nature, whereas the Mag-13 site appears to have an intact hull. The higher entropy of a disarticulated wreck, in theory, should result in a

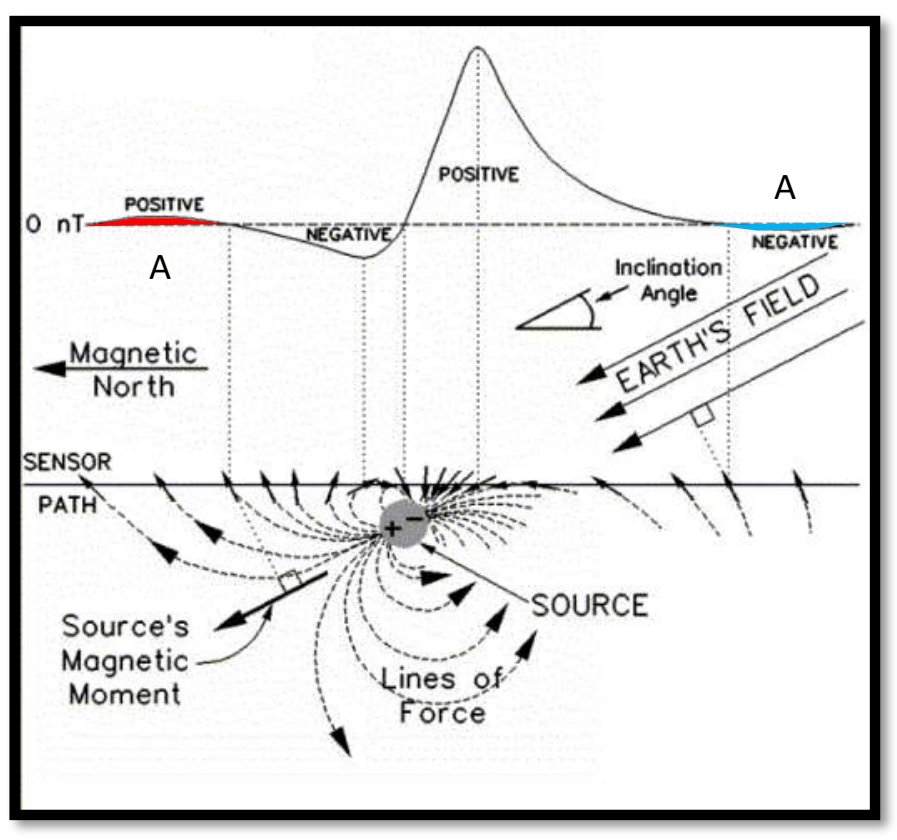

Figure 6: Induced Magnetic Anomaly lower peak amplitude and a smaller magnetic footprint, all other things being equal, than if the same wreck were an intact hull. Unfortunately, the original hull dimensions of 41 CL92 are unknown. Although it represents the smallest anomaly known to date for a disarticulated wooden wreck, smaller examples likely exist. A realistic lower limit for the dimensions of a significant anomaly remains open for debate. In the meanwhile, a working estimate is suggested below.

The smallest likely size of historic commercial watercraft in the Gulf Coast trade can be determined through research. For example, the average size of wooden sailing vessels registered in the Port of New Orleans during the period 1804-1820 was $71 \times 21 \mathrm{ft}(21.6 \times 6.4 \mathrm{~m})$ (based on Works Progress Administration [1941] as summarized in Ford et al. 2008: 54-71). The smallest vessel registered in New Orleans during the same period was the schooner Tickler, which measured only $29 \times 10 \mathrm{ft}(8.8 \times 3.0 \mathrm{~m})$ (Works Progress Administration 1941: 127), roughly 81 percent the size of the Mag-13 hull.

It seems reasonable, based on comparison with the Mag-13 wreck, that an intact wooden vessel as small as Tickler might have an anomaly measuring as much as 81 percent smaller than the Mag-13 anomaly, that is to say $160 \times 133 \mathrm{ft}(48.8 \times 40.5 \mathrm{~m})$ across, or an average diameter of $147 \mathrm{ft}$. The 41CL92 anomaly, 
the smallest verified wreck anomaly known to this author, measures 92 percent smaller than the Mag-13 wreck anomaly, possibly because the site is disarticulated. To be conservative, the hypothetical anomaly size for Tickler, likewise, has been adjusted downward by 92 percent, yielding an estimate of $147 \times 122 \mathrm{ft}$ $(44.8 \times 37.2 \mathrm{~m})$, or an average diameter of $135 \mathrm{ft}(41.1 \mathrm{~m})$. This author, therefore, will consider dipoles potentially significant if they align with magnetic north and have a minimum horizontal dimension of at least $135 \mathrm{ft}(41.1 \mathrm{~m})$, which is 81 percent smaller than the 41CL92 anomaly.

\section{Orientation}

Shipwreck anomalies (e.g., Figures 4, 5, 7, and 8) consistently share a common orientation with respect to earth's magnetic field, despite the great diversity of wrecks described above. All wreck anomalies observed by this author, to date, are oriented with their primary negative pole situated north of their positive pole. The local direction of magnetic north agrees, on average, within +/-10 degrees of the dipole alignment for 29 verified wreck anomalies, reported in Gearhart (2011b). The maximum reported difference between dipole alignment and magnetic north direction was 26 degrees. A similar orientation

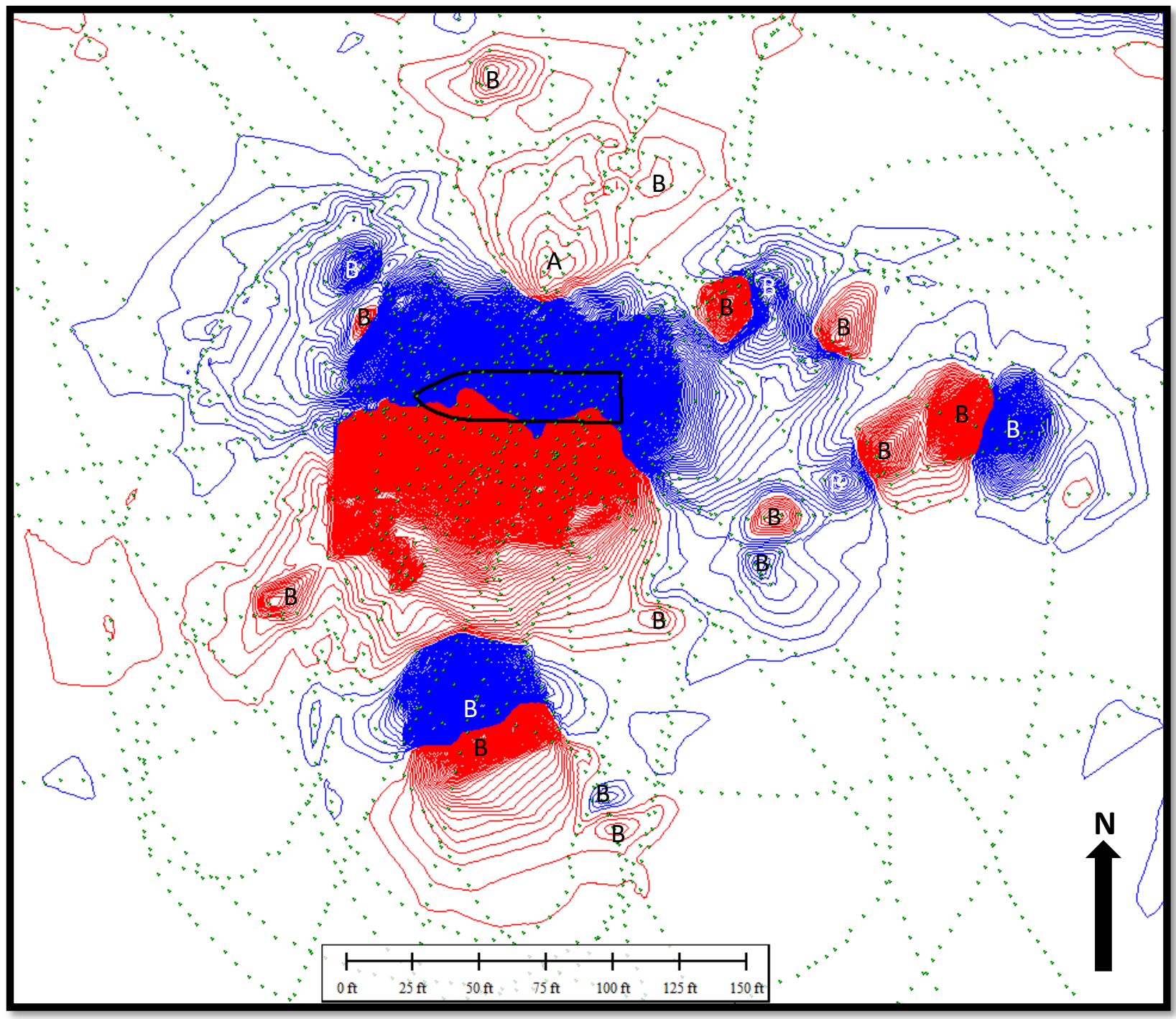

Figure 7: 41CH372 Anomaly (steel hull), 5-nT contour interval 
is expected of all wrecks, as well as all other complex anomaly sources, in mid-latitudes of the northern hemisphere; however, the orientation of anomalies over simple debris sources is not limited.

Shipwrecks, and other complex sources, have anomalies closely aligned to the direction of magnetic north. This phenomenon is believed due to the random orientations of many individual magnetic components that make up each complex source, including shipwrecks. The magnetic field of each component interacts with that of its neighbors. The overlapping portions of fields that oppose one another in direction tend to cancel, while lines of force that run in the same general direction reinforce each other. Since a small portion of each field is aligned with (induced by) earth's local field, the net result of all these interactions is that more reinforcement occurs in the direction of magnetic north than in any other direction, resulting in a north-aligned anomaly. A simple debris source, on the other hand, is a solitary object on the seabed. By definition, there are no nearby sources affecting its magnetic field, thus the alignment of its anomaly primarily is determined not by earth's magnetic field direction but by the object's orientation on the seabed. Hence debris anomalies can be oriented along any point of the compass.

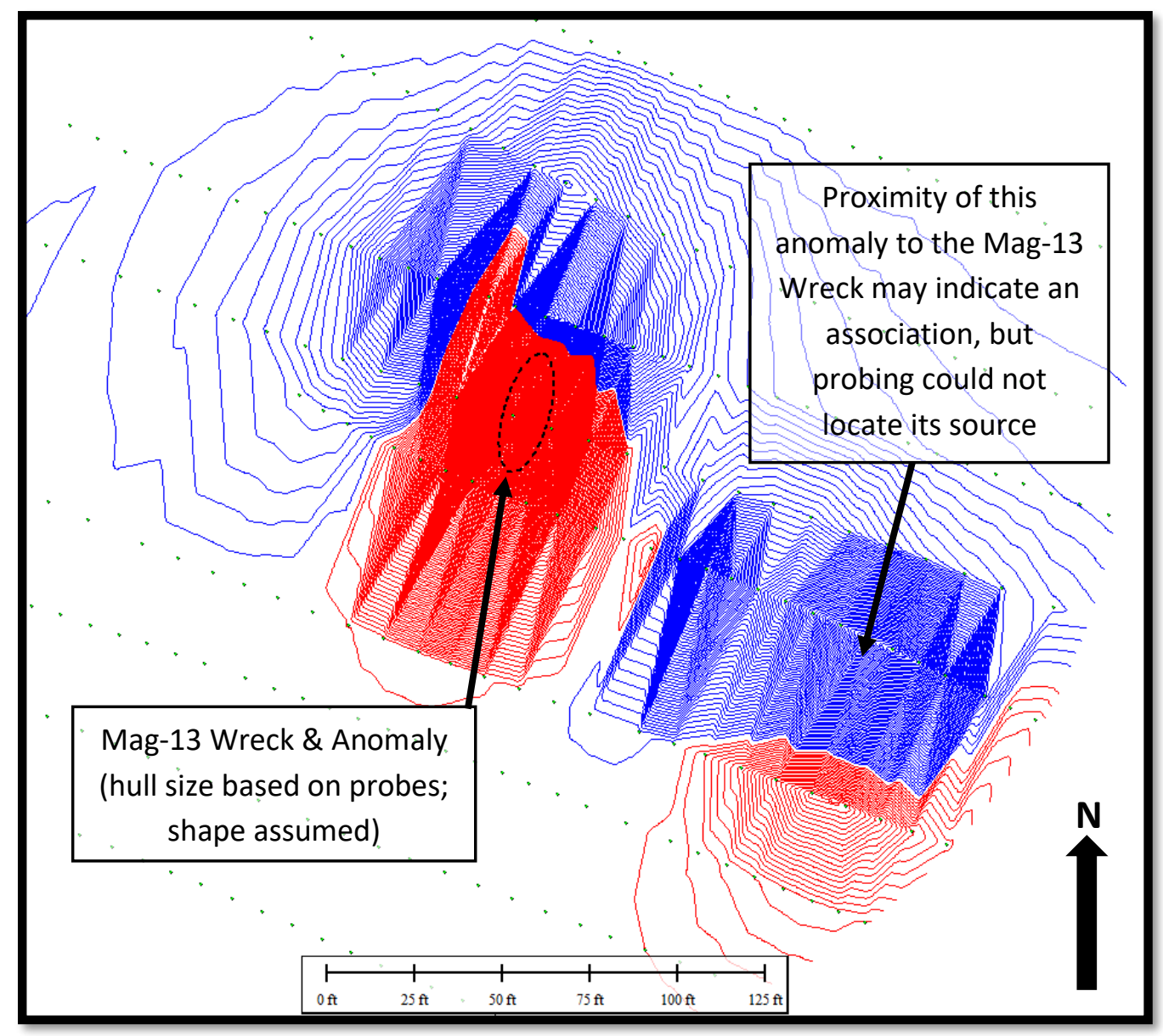

Figure 8: Mag-13 Wreck Anomaly (wooden hull) 5-nT contour interval (Gearhart 2016: 46) 
Consideration of anomaly orientation may be used to differentiate magnetic anomalies caused by most simple debris sources from anomalies caused by complex sources, including shipwrecks, and has potential to eliminate close to 80 percent of debris anomalies from further archaeological concern. Roughly 20 percent of simple debris sources have northerly orientations like those observed over complex sources. Absent a sonar target, there is no reliable method known, short of physically probing an anomaly, to differentiate that 20 percent of debris having northerly orientations from complex sources, including potential buried shipwrecks.

Anomalies can be eliminated from consideration as potential shipwrecks by demonstrating that their orientations differ substantially from the direction of magnetic north. It seems unlikely that a shipwreck could have a magnetic anomaly that is not aligned closely with magnetic north, as this would require a large percentage of the wreck's many ferromagnetic components, by chance, to have the same magnetic moment. On the other hand, the anomaly of a simple debris source should align with earth's magnetic field only when its magnetic moment, as determined by the source's orientation on the seafloor, closely aligns with magnetic north.

The interpretation of magnetic anomalies based on orientation requires comparing unidentified magnetic anomalies, contoured at a 5-nT interval, to the anomaly of a small, verified wreck anomaly, such as 41 CL92, shown in Figure 4. One must ensure that the reference anomaly is contoured, oriented and scaled using the same parameters as the survey data to which it is compared. Anomalies having a polar orientation similar to that of 41CL92 should be considered possible shipwrecks unless contradicted by other information, such as reliable evidence of an abandoned petroleum well nearby, as anomalies over steel well casings often closely resemble shipwreck anomalies. Information regarding petroleum infrastructure is available on the TxRRC Public GIS Viewer to rule out association with wells.

\section{Significance Criteria}

BOB's minimum criteria for potential archaeological significance of magnetic anomalies (in mid-latitudes of the northern hemisphere) requires that an anomaly, when surveyed at 20-m intervals, be consistent with the following conditions: a) it must have at least one dipole, oriented with its negative pole north of its positive pole; b) it should be at least $135 \mathrm{ft}(41.1 \mathrm{~m}$ ) across (to the +/- 5-nT contour); and c) it should appear on a minimum of 2 transects. If survey lines are spaced at 10-m intervals, a significant anomaly should meet all of the above conditions and d) should appear on at least 4 transects. An anomaly's shape usually is not obvious if data is from a single survey transect; thus, additional criteria have been designed to avoid missing significant targets. If survey lines are spaced at 30-m intervals, a significant anomaly e) may be limited to a single transect; and f) may appear as a monopole, provided the transect follows a predominantly east-west heading. Exceptions may be made in either direction, at the Principal Investigator's discretion, based on mitigating circumstances or professional judgment. Resemblance to verified shipwreck anomalies, including the 39 reported by Gearhart (2011b, 2016), should be an important factor in such judgments when close-order survey has been conducted. 


\section{Results}

No significant geophysical targets were discovered by this survey. Side-scan sonar data is illustrated as a mosaic image in figures 9 and 10. No potential shipwrecks were discovered by the sonar survey, and no sonar targets correlate with magnetic anomalies. A linear sonar feature, interpreted as a submerged breakwater, crosses the survey corridor near its eastern end. This feature is visible on 2015 aerial photography and aligns with a visible rock breakwater.

Magnetic contours are illustrated in figures 11 and 12 . None of the magnetic anomalies discovered by this survey meet BOB's minimum criteria for archaeological significance described in Section IV above. Some of the very smallest anomalies are associated with crab traps. All of the other anomalies are interpreted as debris. Information regarding petroleum infrastructure was checked on the Railroad Commission of Texas' Public GIS Viewer. No wells or pipelines are reported near the survey area.

\section{Recommendations}

No geophysical targets are recommended for avoidance and none are believed to meet criteria for State Antiquities Landmark or NRHP eligibility. BOB recommends cultural resource clearance for all portions of the archaeological survey.

Avoidance buffers are mandated by The Texas Administrative Code, Title 13, Part 2, Chapter 26. The buffer for inshore waters is set at $50 \mathrm{~m}(164 \mathrm{ft}$ ) beyond significant target boundaries and around the perimeter of project-related seafloor disturbances. Disturbance of the seafloor must be avoided within this mandated buffer width around the proposed access channel. If shipwreck remains, or other potentially historic materials, are discovered anywhere in the survey area during construction, work should be halted within $50 \mathrm{~m}(164 \mathrm{ft})$ of the find until the THC can provide guidance concerning the discovery. 


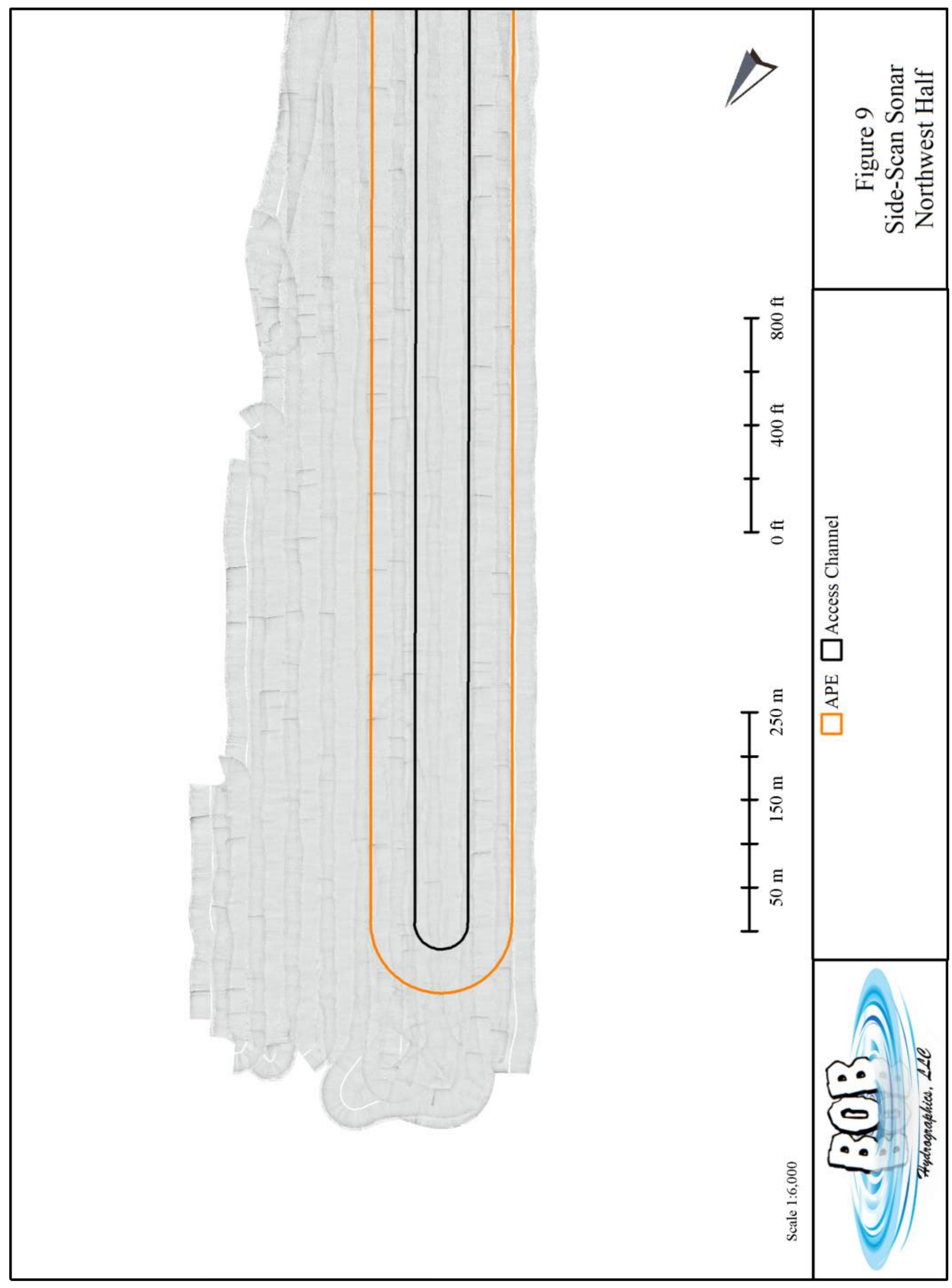




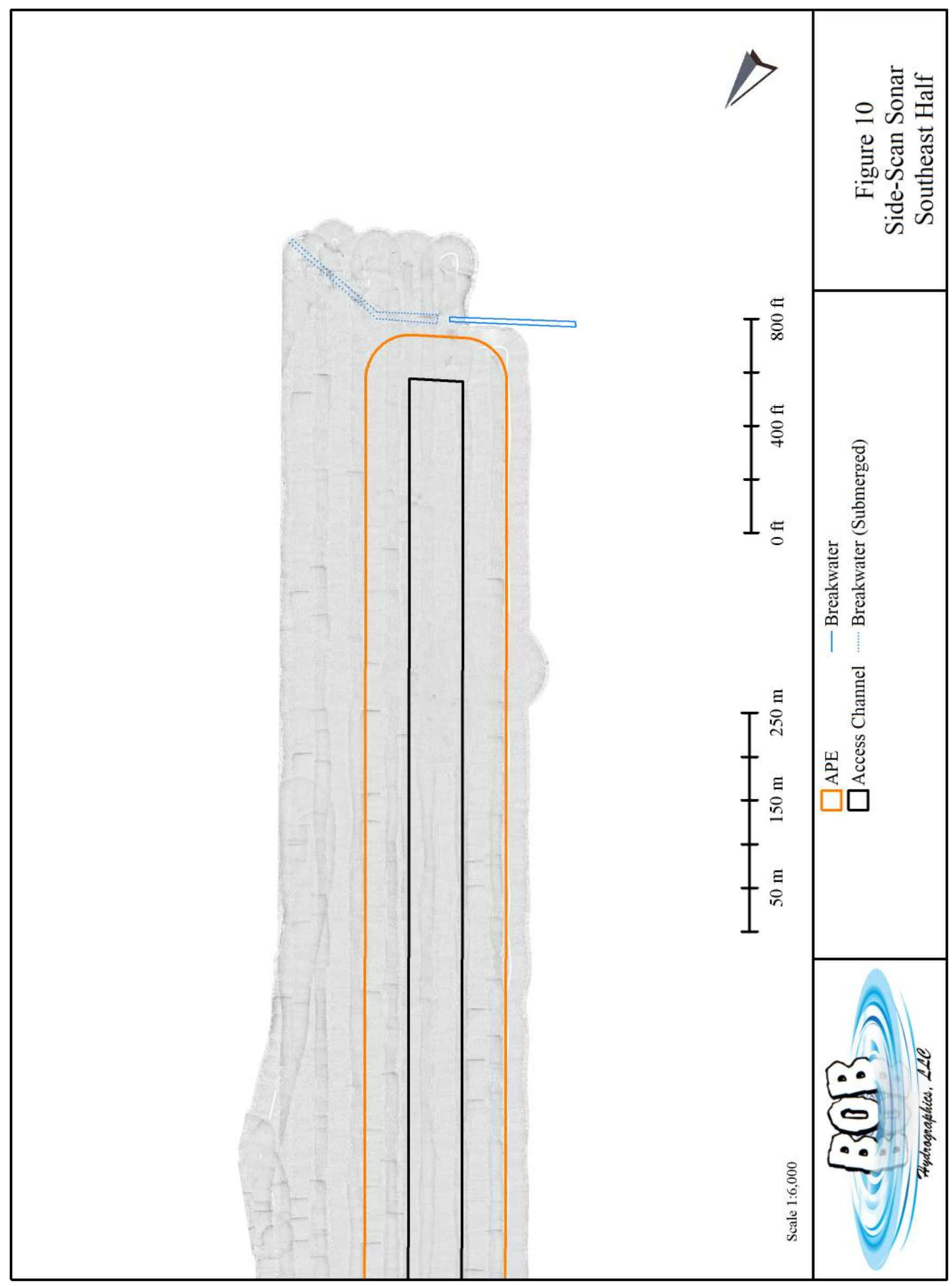




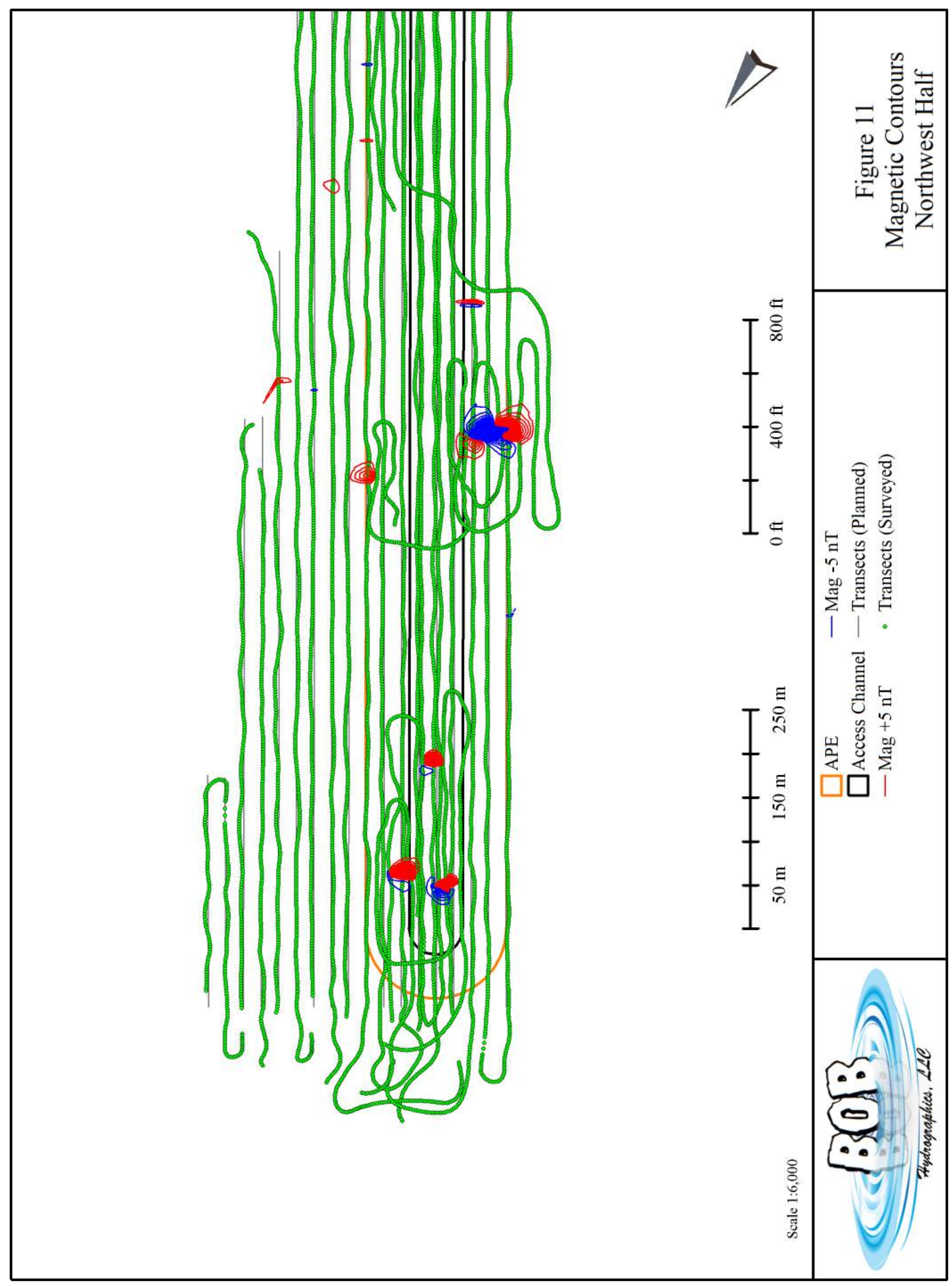




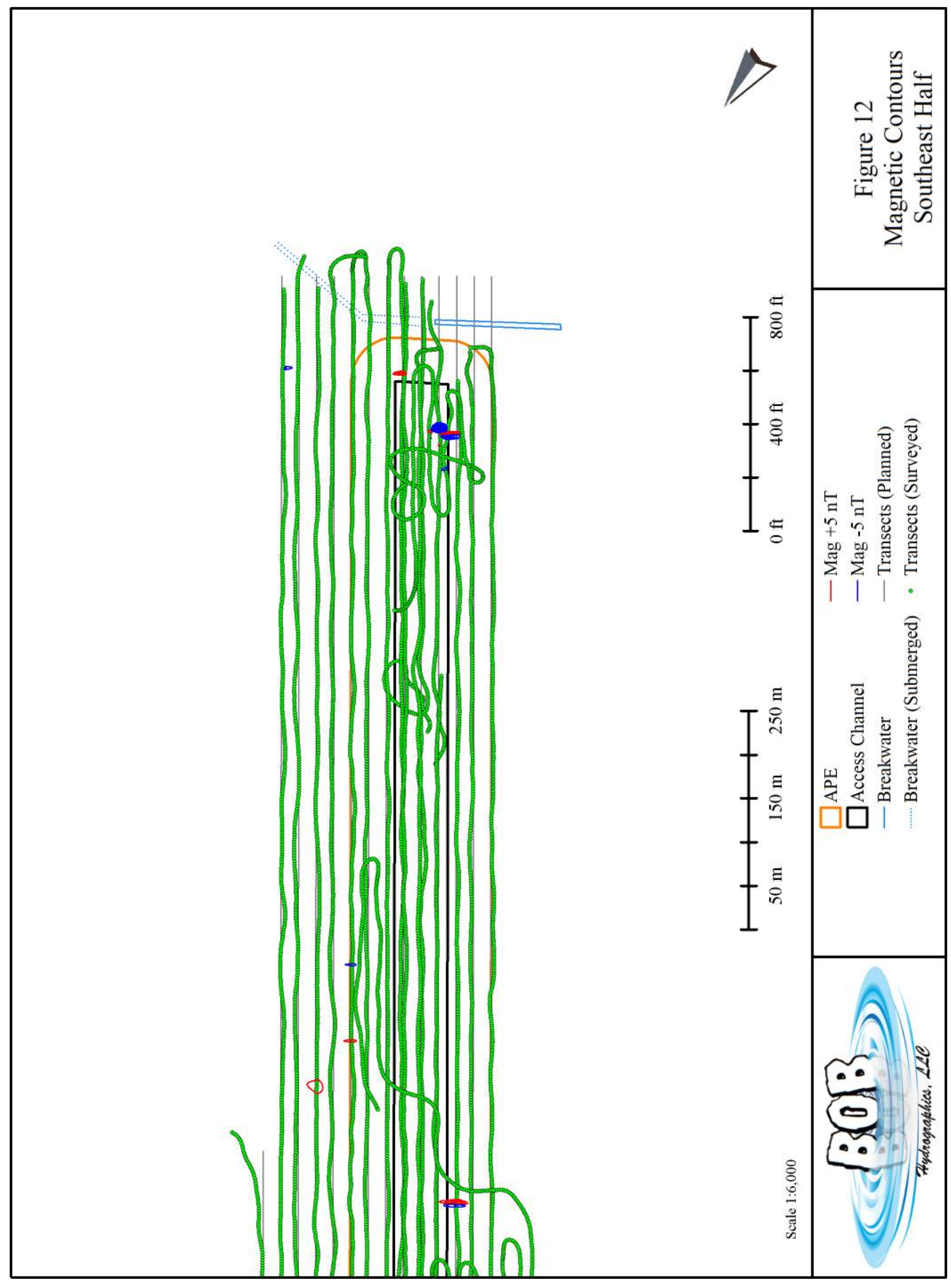




\section{References Cited}

Alperin, Lynn. 1977. Custodians of the Coast: History of the United States Army Engineers at Galveston. Galveston District, United States Army Corps of Engineers.

Borgens, Amy. 2004. Analysis of the Pass Cavallo Wreck Assemblage, Matagorda Bay, Texas. Master's thesis, Texas A\&M University, College Station.

Cabeza de Vaca, Álvar Núñez. 2013. Chronicle of the Narváez Expedition, Translation of 'La Relacion', translated by David Frye, edited by Ilan Stavans. Norton Critical Edition.

Chipman, Donald E., and Harriett Denise Joseph. 2010. Spanish Texas 1519-1821, Revised Edition. University of Texas Press, Austin.

Cotham, Edward T. Jr. 1998. Battle on the Bay: The Civil War Struggle for Galveston. University of Texas Press, Austin.

Davis, William C. 2005. The Pirates Lafitte: The Treacherous World of the Corsairs of the Gulf. Harcourt, Inc. Austin, Texas.

Folmer, Henri. 1940. De Bellisle on the Texas Coast, Southwestern Historical Quarterly 44 (2), October 1940.

Ford, B., A. Borgens, W. Bryant, D. Marshall, P. Hitchcock, C. Arias and D. Hamilton. 2008. Archaeological excavation of the Mardi Gras Shipwreck (16GM01), Gulf of Mexico Continental Slope. OCS Report MMS 2008-037. U.S. Department of Interior, Minerals Management Service, Gulf of Mexico OCS Region, New Orleans.

Foster, Eugene and Robert Gearhart. 1991. A Survey and Assessment of Cultural Resources at Eckert Bayou, Galveston County, Texas. Texas Antiquities Permit 1050. Prepared by Espey, Huston \& Associates, Inc. EH\&A Job \#13597. Austin, Texas.

Foster, Eugene, Ty Summerville, and Thomas Brown. 2006. The Texas Historic Overlay: A Geographic Information System of Historic Map Images for Planning Transportation Projects in Texas. PBS\&J Document 060206. Texas Department of Transportation, Environmental Affairs Division, Austin.

Francaviglia, Richard V. 1998. From Sail to Steam: Four Centuries of Texas Maritime History, 1500-1900. University of Texas Press, Austin.

Garrison, E. G., C. P. Giammona, F. J. Kelly, A. R. Tripp and G. A. Wolff. 1989. Historic shipwrecks and magnetic anomalies of the northern Gulf of Mexico: Reevaluation of archaeological resource management zone 1. Volume II: technical narrative. OCS Study, MMS 89-0024. U.S. Department of the Interior, Minerals Management Service, Gulf of Mexico OCS Region.

Gearhart, Robert. 2011a. Wooden Shipwrecks of the Central and Western Gulf of Mexico. Paper presented at Offshore Technology Conference, Houston, Texas. 
Gearhart, Robert. 2011b. Archaeological Interpretation of Marine Magnetic Data, Chapter 4 in The Oxford Handbook of Maritime Archaeology, Alexis Catsambis, Ben Ford, and Donny L. Hamilton, editors, pp. 90-113. Oxford University Press, New York, New York.

Gearhart II, Robert. 2016. Marine Archaeological Survey of Proposed North Jetty Sand Search, Galveston County, Texas. Prepared for HDR Engineering, Inc. Surveying And Mapping, LLC, Austin, Texas.

Gearhart, Robert, John Neville, and Steven Hoyt. 1990. California, Oregon, and Washington Archaeological Resource Study, Volume IV: History. Prepared for Minerals Management Services, Pacific Region. OCS Study MMS 90-0090. Espey, Huston \& Associates, Inc., Austin, Texas.

Hamilton, Donny. 2010. Methods of Conserving Archaeological Material from Underwater Sites, Revision No. 2. Conservation Files: ANTH 605, Conservation of Cultural Resources I. Nautical Archaeology Program, Texas A\&M University, World Wide Web, http://nautarch.tamu.edu/CRL/conservationmanual/, last accessed on 27 May 2019.

Hole, Frank (General Editor). 1982. The Quintanna Townsite, Brazoria County, Texas (Draft). Prepared for Old River Company / DSI Terminal. Reports in Archaeology No. 1. Department of anthropology, Yale University, New Haven, Connecticut.

Hoyt, Steven, Eugene Foster, Victor Galan, and James Schmidt. 1999. Reconnaissance-Level Study of Historic Period Resources, Selected Areas Along the GIWW, High Island to Brazos River Floodgate, Brazoria, Chambers, and Galveston Counties, Texas. Prepared for the United States Army Corps of Engineers, Galveston District by PBS\&J. Document 970729. Austin, Texas.

Linden, Sarah and Charles Pearson. 2014. Phase I Marine Cultural Resources Remote-Sensing Survey in Buffalo Bayou for the Proposed Kinder Morgan Export Terminal, Pasadena, Harris County, Texas. Coastal Environments, Inc. Corpus Christi, Texas.

Lugo-Fernandez, A., D.A. Ball, M. Gravois, C. Horrell, and J.B. Irion. 2007. Analysis of the Gulf of Mexico's Veracruz-Havanna Route of La Flota de la Nueva España. Journal of Maritime Archeology (2007) 2:24-47.

McDonald, David, and J. Barto Arnold III. 1979. Documentary Sources for the Wreck of the New Spain Fleet of 1554. Texas Antiquities Committee, Publication \#8. Austin.

McGowen, J.H., L.F. Brown, Jr., T.J. Evans, W.L. Fisher, and C.G. Groat. 1976. Environmental Geologic Atlas of the Texas Coastal Zone - Bay City-Freeport Area. Bureau of Economic Geology, The University of Texas at Austin.

Myers, Allan. 1998. A Cultural Resource Assessment of the Brazos Canal, City of Lake Jackson, Brazoria County, Texas. Moore Archaeological Consulting Report of Investigations Number 199. July 1998.

Pearson, Charles E. and Paul E. Hoffman. 1995. The Last Voyage of El Nuevo Constante: The Wreck and Recovery of an Eighteenth-Century Spanish Ship Off the Louisiana Coast. Louisiana State University Press, Baton Rouge.

Unidentified. Circa 1865. Eastern Portion of Galveston Island and its Defenses. National Archives, Record Group 77, Civil Works, College Park, Maryland. Copy on file at the Texas Historical Commission, Austin. 
United States Coast and Geodetic Survey. 1918. Galveston Bay, Texas. Chart 204. U.S. Department of Commerce. Galveston Bay and entrance from surveys by Corps of Engineers, U.S.A. to 1917.

United States Department of the Treasury. 1906-1946. Annual List of Merchant Vessels of the United States. U.S. Government Printing Office, Washington, D.C.

Weddle, Robert S. 1991. The French Thorn: Rival Explorers in the Spanish Sea, 1682-1762. Texas A\&M University Press, College Station, Texas.

Weddle, Robert S. 2001. The Wreck of the Belle, the Ruin of La Salle. The Texas Historical Commission.

Works Progress Administration. 1941. Ship Registers and Enrollments of New Orleans, Louisiana, Volume I (1804-1820). Prepared by the Survey of Federal Archives in Louisiana, Division of Community Service Programs. T.S. Hill Memorial Library, Louisiana State University, Baton Rouge. 
Appendix A: Texas Antiquities Permit 8906 and THC Correspondence

A-1 | P a g e 


\section{TEXAS HISTORICAL COMMISSION \\ real places telling real stories}

Friday, May 03, 2019

Robert Gearhart

BOB Hydrographics, LLC

1315 Fall Creek Loop

Cedar Park, TX 78613-5820

Re: $\quad$ Project review under the Antiquities Code of Texas

Final Report: Galveston Island State Park Marsh Restoration and Protection Project

Texas Antiquities Permit \# 8906

Dear Colleague:

Thank you for your Antiquities Permit Application for the above referenced project. This letter presents the final copy of the permit from the Executive Director of the Texas Historical Commission (THC), the state agency responsible for administering the Antiquities Code of Texas.

Please keep this copy for your records. The Antiquities Permit investigations requires the production and submittal of one printed copy of the final report, a completed abstract form submitted via our online system, two copies of the tagged PDF final report on CD (one with site location information \& one without), and verification that any artifacts recovered and records produced during the investigations are curated at the repository listed in the permit. The abstract form maybe submitted via the THC website (www.thc.state.tx.us) or use url:

http://xapps.thc.state.tx.us/Abstract/login.aspx

Additionally, you must send the THC shapefiles showing the boundaries of the project area and the areas actually surveyed via email to archeological_projects@thc.texas.gov.

If you have any questions concerning this permit or if we can be of further assistance, please contact the reviewer, Amy Borgens at (512) 463-9505.

Sincerely,

Nick Barrett:

Antiquities Permit Coordinator

(512) 463-1858

Enclosures

Cc :Texas General Land Office 


\title{
State of Texas \\ TEXAS ANTIQUITIES COMMITTEE
}

\author{
ARCHEOLOGY PERMIT 8906
}

This permit is issued by the Texas Historical Commission, hereafter referred to as the Commission, represented herein by and through its duly authorized and empowered representatives. The

Commission, under authority of the Texas Natural Resources Code, Title 9, Chapter 191, and subject to the conditions hereinafter set forth, grants this permit for:

\section{Intensive Survey}

To be performed on a potential or designated landmark or other public land known as:

Title: $\quad$ Galveston Island State Park Marsh Restoration and Protection Project

County: Galveston

Location: Near the enterance of Oak Bayou at Galveston Island State Park, on the island side of West Galveston Bay

Owned or Controlled by: (hereafter known as the Permittee):

\section{Texas General Land Office}

1700 N. Congress Ave. Ste 935

Austin TX 78701

Sponsored by (hereafter known as the Sponsor

Texas General Land Office

1700 N. Congress Ave. Ste 935

Austin TX 78701

The Principal Investigator/Investigation Firm representing the Owner or Sponsor is:

Robert Gearhart

BOB Hydrographics, LLC

1315 Fall Creek Loop

Cedar Park, TX 78613-5820

This permit is to be in effect for a period of:

1 Years and 0 Months

and Will Expire on:

05/03/2020

During the preservation, analysis, and preparation of a final report or until further notice by the Commission, artifacts, field notes, and other data gathered during the investigation will be kept temporarily at:

BOB Hydrographics, LLC

Upon completion of the final permit report, the same artifacts, field notes, and other data will be placed in a permanent curatorial repository at:

Center for Archaeological Studies

Scope of Work under this permit shall consist of:

Underwater Survey, see attached scope for detail. 


\section{This permit is granted on the following terms and conditions:}

1) This project must be carried out in such a manner that the maximum amount of historic, scientific, archeological, and educational information will be recovered and preserved and must include the scientific, techniques for recovery, recording, preservation and analysis commonly used in archeological investigations. All survey level investigations must follow the state survey standards and the THC survey requirements established with the projects sponsor(s).

2) The Principal Investigator/Investigation Firm, serving for the Owner/Permittee and/or the Project Sponsor, is responsible for insuring that specimens, samples, artifacts, materials and records that are collected as a result of this permit are appropriately cleaned, and cataloged for curation. These tasks will be accomplished at no charge to the Commission, and all specimens, artifacts, materials, samples, and original field notes, maps, drawings, and photographs resulting from the investigations remain the property of the State of Texas, or its political subdivision, and must be curated at a certified repository. Verification of curation by the repository is also required, and duplicate copies of any requested records shall be furnished to the Commission before any permit will be considered complete.

3) The Principal Investigator/Investigation Firm serving for the Owner/Permittee, and/or the Project Sponsor is responsible for the publication of results of the investigations in a thorough technical report containing relevant descriptions, maps, documents, drawings, and photographs. A draft copy of the report must be submitted to the Commission for review and approval. Any changes to the draft report requested by the Commission must be made or addressed in the report, or under separate written response to the Commission. Once a draft has been approved by the Commission, one (1) printed, unbound copy of the final report containing at least one map with the plotted location of any and all sites recorded and two copies of the report in tagged PDF format on an archival quality CD or DVD shall be furnished to the commission. One copy must include the plotted location of any and all sites recorded and the other should not include the site location data. A paper copy and an electronic copy of the completed Abstracts in Texas Contract Archeology Summary Form must also be submitted with the final report to the Commission. (Printed copies of forms are available from the Commission or also online at www.thc.state.tx.us.)

4) If the Owner/Permittee, Project Sponsor or Principal Investigator/Investigation Firm fails to comply with any of the Commission's Rules of Practice and Procedure or with any of the specific terms of this permit, or fails to properly conduct or complete this project within the allotted time, the permit will fall into default status. A notification of Default status shall be sent to the Principal Investigator/Investigation Firm, and the Principal Investigator will not be eligible to be issued any new permits until such time that the conditions of this permit are complete or, if applicable, extended.

5) The Owner/Permittee, Project Sponsor, and Principal Investigator/Investigation Firm, in the conduct of the activities hereby authorizes, must comply with all laws, ordinances and regulations of the State of Texas and of its political subdivisions including, but not limited to, the Antiquities Code of Texas; they must conduct the investigation in such a manner as to afford protection to the rights of any and all lessees or easement holders or other persons having an interest in the property and they must return the property to its original condition insofar as possible, to leave it in a state which will not create hazard to life nor contribute to the deterioration of the site or adjacent lands by natural forces.

6) Any duly authorized and empowered representative of the Commission may, at any time, visit the site to inspect the fieldwork as well as the field records, materials, and specimens being recovered.

7) For reasons of site security associated with historical resources, the Project Sponsor (if not the Owner/Permittee), Principal Investigator, Owner, and Investigation Firm shall not issue any press releases, or divulge to the news media, either directly or indirectly, information regarding the specific location of, or other information that might endanger those resources, or their associated artifacts without first consulting with the Commission, and the State agency or political subdivision of the State that owns or controls the land where the resource has been discovered.

8) This permit may not be assigned by the Principal Investigator/Investigation Firm, Owner/Permittee, or Project Sponsor in whole, or in part to any other individual, organization, or corporation not specifically mentioned in this permit without the written consent of the Commission. 9) Hold Harmless: The Owner/Permittee hereby expressly releases the State and agrees that Owner/Permittee will hold harmless, indemnify, and defend (including reasonable attorney's fees and cost of litigation) the State, its officers, agents, and employees in their official and/or individual capacities from every liability, loss, or claim for damages to persons or property, direct or indirect of whatsoever nature arising out of, or in any way connected with, any of the activities covered under this permit. The provisions of this paragraph are solely for the benefit of the State and the Texas Historical Commission and are not intended to create or grant any rights, contractual or otherwise, to any other person or entity.

10) Addendum: The Owner/Permittee, Project Sponsor and Principal Investigator/Investigation Firm must abide by any addenda hereto attached.

Upon a finding that it is in the best interest of the State, this permit is issued on 05/03/2019.
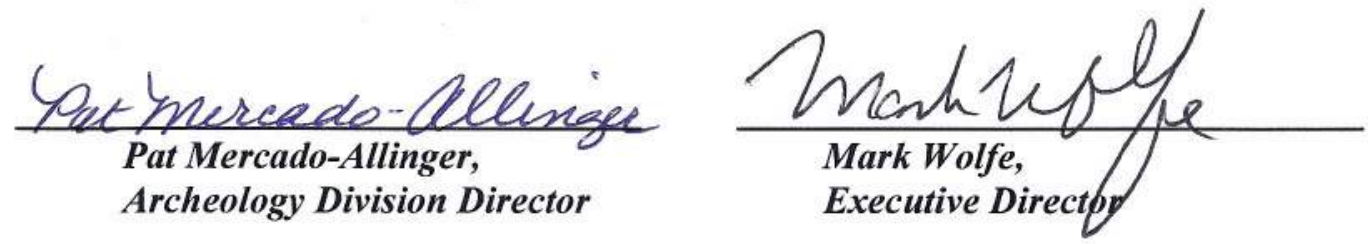


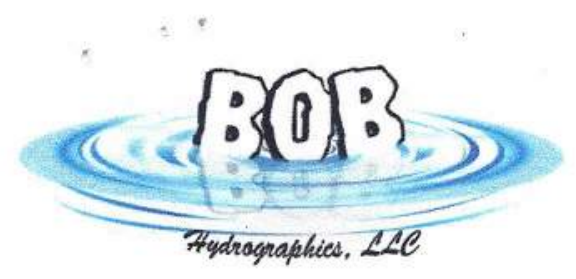

May 28, 2019

Amy Borgens

State Marine Archaeologist

Texas Historical Commission

108 West 16 th Street

Austin, Texas 78711

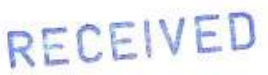

RE: Antiquities Permit 8906; Galveston Island State Park Marsh Restoration and Protection Project, Galveston County; draft report transmittal

Dear Ms. Borgens:

BOB Hydrographics, LLC (BOB) is pleased to deliver a marine archaeology survey report (printed draft) for the above-referenced project. I would appreciate your review of this report, on behalf of my client, HDR Engineering, Inc. BOB conducted a marine geophysical survey and archaeological assessment of a proposed construction access channel in Galveston County, on behalf of HDR Engineering, Inc. A proposed 25-acre bay access channel would cross portions of State Mineral Lease Tracts, West Bay 59, 65 and 66 in West Galveston Bay. The channel would provide construction access to build a breakwater for the Galveston Island State Park Marsh Protection and Restoration Project, sponsored by the General Land Office.

An archaeological survey was requested by the U.S. Army Corps of Engineers, Galveston District, based on their review of Permit Application SWG-1998-02298. Consultation between the Texas Historical Commission and the Galveston District concluded that archaeological survey only would be required for the channel providing access from the bay to the island and not for areas adjacent and including the proposed breakwaters. The area of potential effect encompasses 70 acres, including a 50 -meter buffer mandated by the Texas Historical Commission around the proposed channel. A review of cultural background determined that 1 marine archaeological investigation and, at least, 1 wreck have been reported within 3 miles of the survey area.

BOB completed a marine geophysical survey on May 9, 2019 under Texas Antiquities Permit 8906. A total of 140 acres was surveyed to provide options for adjusting the route if necessary. Water depth at the time of the survey ranged from 4 to 9 feet. BOB assessed all geophysical data to locate archaeological sites potentially affected by construction of the access channel. No artifacts were collected during the survey. No significant geophysical targets were discovered that might be potentially eligible for the State Antiquities Landmark or for the National Register of Historic Places. BOB recommends cultural resource clearance for all areas surveyed, provided that a THC-mandated 50-meter buffer is honored around the perimeter of the survey area.

Please don't hesitate to contact me if you have any questions or concerns. I can be reached any time at $512-$ 517-8564 or by email at BOB.hydrographics@gmail.com.

All my best,

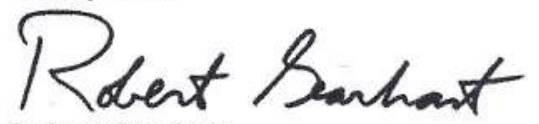

Robert Gearhart

Owner

cc: Daniel Heilman, HDR Engineering, Inc.

Kelly Brooks, Texas General Land Office

Cherie O'Brien, Texas Parks and Wildlife Department

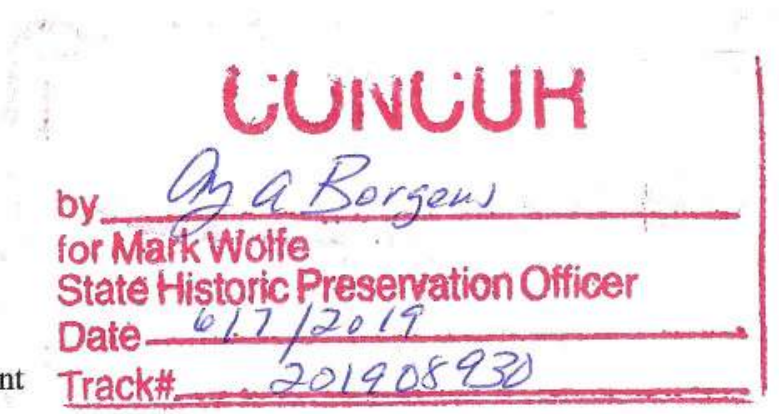

\section{A-5 | Page}

